\title{
Processes affecting molecular and stable isotope compositions of sediment gas in estuarine waters along the southern Baltic coast (Poland)
}

\author{
Michał Woszczyk (iD) Maciej J. Kotarba • \\ Michael Whiticar $\cdot$ Carsten Schubert
}

Received: 30 March 2016/Accepted: 4 November 2016/Published online: 18 November 2016

(C) The Author(s) 2016. This article is published with open access at Springerlink.com

\begin{abstract}
This paper investigates the molecular and stable isotope compositions of sediment gases from seven coastal lakes along the southern Baltic coast in Poland. The aim is to extend the knowledge of the genesis and distribution of microbial gases in the zone of mixing of fresh and salt waters with special attention to the effect of salinity, climate-related seasonality, and vertical sediment mixing. We found differences in the compositions of gas between the studied lakes and within each lake. These differences are mainly controlled by lake water depth and the presence of macrophytes. Due to the dissolution of rising bubbles in highly oxygenated water, the concentrations of $\mathrm{CH}_{4}$
\end{abstract}

Responsible Editor: Leila J. Hamdan.

M. Woszczyk ( $\bowtie)$

Department of Quaternary Geology \& Paleogeography, Adam Mickiewicz University, B. Krygowskiego 12,

61-680 Poznan, Poland

e-mail: woszczyk@amu.edu.pl

M. J. Kotarba

Department of Environmental Analyses, Cartography and Economical Geology, AGH University of Science and Technology, Mickiewicza 30, 30-059 Kraków, Poland

\section{Whiticar}

School of Earth and Ocean Sciences, University of Victoria, PO Box 3055, Victoria, BC, Canada

\section{Schubert}

Surface Water Research and Management, EAWAG, Seestrasse 79, 6047 Kastanienbaum, Switzerland and $\mathrm{CO}_{2}$ show up to $67 \%$ decline along the water column in favor of $\mathrm{N}_{2}$ and $\mathrm{O}_{2}$. On the other hand, in vegetated parts of the lakes, the $\mathrm{CH}_{4}$ is depleted in favor of $\mathrm{CO}_{2}$, and the residual $\mathrm{CH}_{4}$ and $\mathrm{CO}_{2}$ are enriched in ${ }^{13} \mathrm{C}$. Despite the fact that the coastal lakes display highly oxidizing conditions in the water column and that the bottom sediments are mixed by wind waves the $\mathrm{CH}_{4}$ reveals rather low oxidation. On the basis of the $\mathrm{CH}_{4} / \mathrm{N}_{2}$ ratio we established that there are differences in the intensity of ebullition throughout the lakes. Higher intensities of ebullition were found in shallower parts of the lakes. Salinity has no effect on the stable $\mathrm{C}$ and $\mathrm{H}$ isotope composition of sediment gas. It seems, however, that salinity affects the molecular composition of hydrocarbons via preferential oxidation of $\mathrm{CH}_{4}$ under higher salinity conditions.

Keywords Greenhouse gas - Coastal lake · Biogeochemistry $\cdot$ Stable isotopes $\cdot$ Baltic

\section{Introduction}

Substantial increases in tropospheric $\mathrm{CH}_{4}$ and $\mathrm{CO}_{2}$ over the past decades and the attendant climatic implications have prompted renewed studies on the productivity and emission of greenhouse gases from marine and terrestrial ecosystems.

Estuaries, where marine and fresh waters mix, are one of the largest sources of atmospheric $\mathrm{CO}_{2}$. The high production of $\mathrm{CO}_{2}$ is a diagenetic consequence of the high delivery 
and remineralization of organic and inorganic $\mathrm{C}$ from upstream rivers and from intense bacterial activity within estuaries (Bauer et al. 2013). Estuaries release from 0.27 to $0.60 \mathrm{Pg} \mathrm{CO}_{2}-\mathrm{C} \mathrm{y}^{-1}$ (Borges and Abril 2011), which is more than the emission from rivers and lakes (Borges et al. 2006; Cole et al. 2007) as well as wetlands (Bauer et al. 2013). In contrast, the contribution of estuaries to the global $\mathrm{CH}_{4}$ budget is uncertain but assumed to be minor (Kirschke et al. 2013). Estimates of total estuarine $\mathrm{CH}_{4}$ emissions vary but are in the range of 0.8-6.6 $\mathrm{Tg} \mathrm{CH}_{4} \mathrm{y}^{-1}$ (Borges and Abril 2011 and references therein). For comparison, wetlands and freshwater lakes and rivers emit 217 and $40 \mathrm{Tg} \mathrm{CH}_{4} \mathrm{y}^{-1}$, respectively (Kirschke et al. 2013). The low contribution of estuaries to global $\mathrm{CH}_{4}$ production and emissions is caused by the effect of salinity on the activity on methanogenic archaebacteria (MA). It is well established for saline environments, replete in dissolved sulphate, that the MA are outcompeted in the sulphates reduction zone (SRZ) by sulphate-reducing bacteria (SRB) for many methanogenic substrates (Whiticar 1999). In addition, anaerobic $\mathrm{CH}_{4}$ oxidation by SRB in the SRZ effectively consumes $\mathrm{CH}_{4}$ that fluxes into the SRZ from deeper layers or is formed locally from non-competitive substrates. Consequently, in saline waters, the zone of methanogenesis and $\mathrm{CH}_{4}$ accumulation is displaced to deeper sediment layers beneath the SRZ. In these environments $\mathrm{CH}_{4}$ is typically produced from more refractory substrates, including hydrogenotrophic methanogenesis $\left(\mathrm{CO}_{2}\right.$ reduction).

Due to their small global areal footprint, estuaries are thought to represent only a small fraction of the global atmospheric $\mathrm{CH}_{4}$ emissions. However, individual estuaries can be highly methanogenic. For example, Bange (2006) and Harley et al. (2015) reported high $\mathrm{CH}_{4}$ saturations in estuarine waters from 62 to $25,700,000 \%$ along the southwestern Baltic coast and from 100 to $13,100 \%$ along the north-western North Sea coast. The biogeochemical literature contains extensive discussion of the potential impact that estuaries will have in response to climate change and the sea level rise (Kjerfve et al. 1994; Scavia et al. 2002; Borges et al. 2006; Day et al. 2008). However, due to uncertainties with regard to the present day emissions of $\mathrm{CH}_{4}$ and $\mathrm{CO}_{2}$ from estuaries the prediction of future emissions of these gases is very complex (Borges and Abril 2011 and references therein). The uncertainties in the $\mathrm{CH}_{4}$ and $\mathrm{CO}_{2}$ fluxes mainly derive from divergent evaluations of the area covered by estuaries throughout the world, as well as from the complexity of the estuarine systems (Borges and Abril 2011).
Spatial and temporal variability in salinity and hydrodynamic conditions in estuaries make it challenging to select representative sites for $\mathrm{CH}_{4}$ and $\mathrm{CO}_{2}$ measurement. There is a need to make measurements at diverse field sites to recognize the controls and distribution of microbial gas production within estuaries. On the Polish, southern coast of the Baltic Sea, estuaries are typically coastal lakes. Cieśliński and Drwal (2005) pointed out that these lakes act as quasiestuaries because there are no tides on this coast and the lakes are only episodically inundated by brackish waters inflowing from the sea during specific anemometric conditions. Woszczyk et al. (2011) suggested that these lakes are potentially a source for $\mathrm{CH}_{4}$. However neither saturation levels nor $\mathrm{CH}_{4}$ fluxes out of the lakes have been determined so far.

This paper provides the first comprehensive study on the sediment gases produced in coastal lakes. The aim of this study is to extend the knowledge of the genesis and distribution of microbial gases in coastal lakes, with special attention to (a) effects of salinity on gas compositions and spatial distribution; (b) climaterelated seasonality in the compositions of sediment gases; (c) pathways of methanogenesis in the salinefreshwater mixing zone; and (d) $\mathrm{CH}_{4}$ oxidation in these shallow water and dynamically mixed environments.

We investigated the bubbles of gas released from the lake sediments via ebullition, the most efficient pathway of gas emission from shallow $(<50 \mathrm{~m})$ and turbulent water bodies (Engle and Melack 2000; Kankaala et al. 2004; McGinnis et al. 2006; Del Sontro et al. 2010; Bastviken et al. 2011). Our approach was to combine the analysis of the molecular and stable isotope compositions of the gas collected in seven lakes along the southern Baltic area over a study period of several months. We provided evidence that the molecular and isotopic compositions of sediment gas show reasonable spatio-temporal variability and that they are prone to substantial transformation in the water column.

\section{Methods}

Study area

The lakes investigated are located along the $150 \mathrm{~km}$ long section of the Poland Baltic Sea coast (Fig. 1). These coastal lakes were formed by isolation from the brackish Baltic Sea in the early-middle Atlantic period 


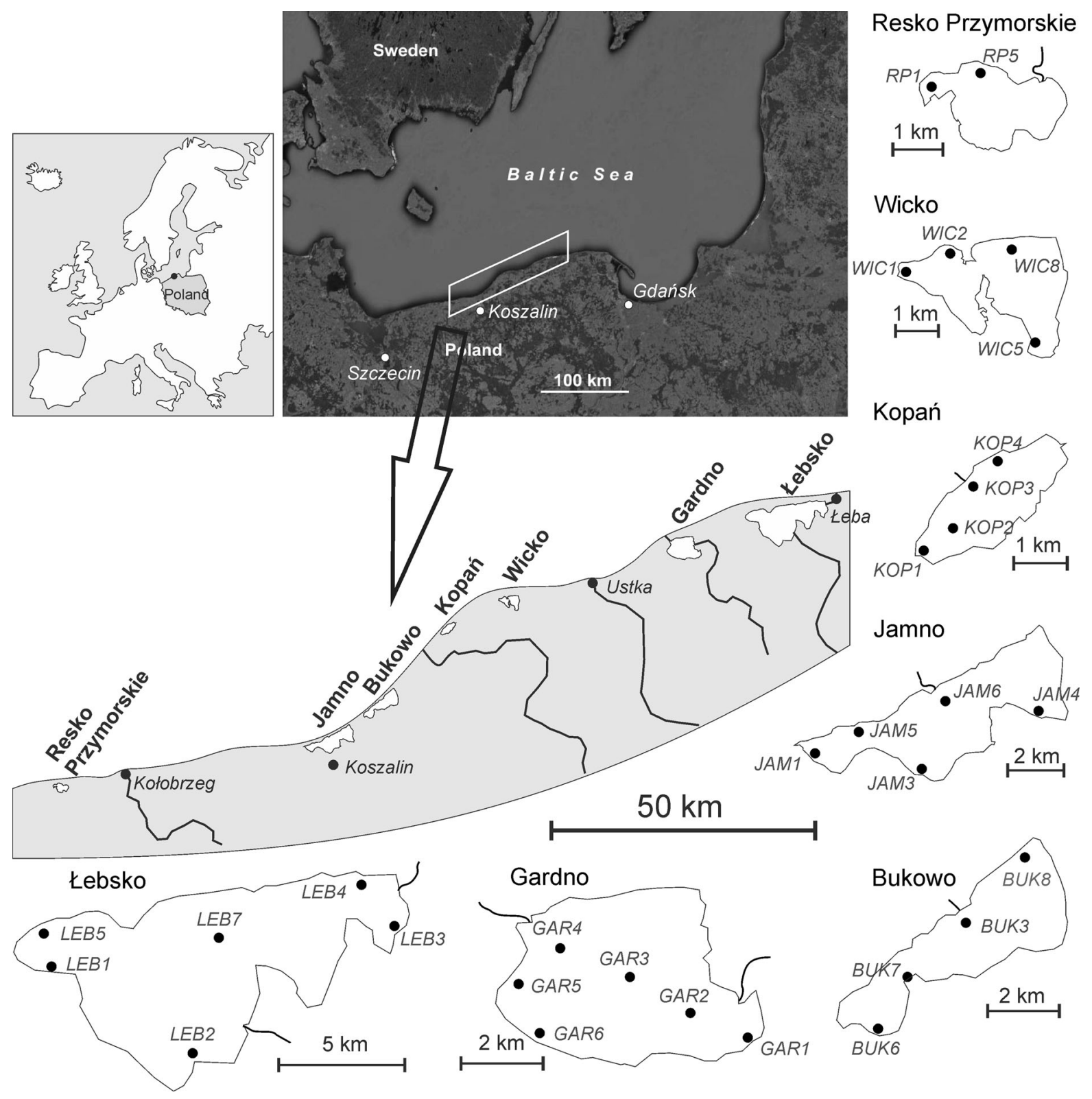

Fig. 1 Location of the seven lakes studied and distribution of sample sites in each lake

(Miotk-Szpiganowicz et al. 2008) and thus preserved some features of lagoons. The lakes are relatively large and shallow (mean water depth is less than $2 \mathrm{~m}$ ) (Table 1) and are oriented parallel to the predominant wind directions (W-SW). These features result in high sensitivity of coastal lakes to wind-driven turbulence (Woszczyk et al. 2014). Consequently, the surface and bottom waters of the lakes were highly oxygenated throughout the sampling period. The dissolved $\mathrm{O}_{2}$ varied from 0.14 to $0.47 \mu \mathrm{mol} \mathrm{L}^{-1}$, and $\mathrm{O}_{2}$ saturation was between 51 and $165 \%$ (Table 1). The highest oxygenation occured during winter, when the highest wind speeds (up to $24 \mathrm{~m} \mathrm{~s}^{-1}$ in Ustka) were observed, and the minimum of dissolved $\mathrm{O}_{2}$ was obtained in summer. Due to the connection to the Baltic Sea, most of the lakes have brackish conditions, however, the salinity has appreciable spatial and temporal variability (Table 1). The salinity (expressed as total dissolved 
Table 1 Location and physical-chemical characteristics of the studied lakes

\begin{tabular}{|c|c|c|c|c|c|c|c|c|c|}
\hline \multirow[t]{2}{*}{ Lake } & \multicolumn{2}{|l|}{ Location* } & \multirow{2}{*}{$\begin{array}{l}\text { Area* } \\
\text { (ha) }\end{array}$} & \multirow{2}{*}{$\begin{array}{l}\text { Mean depth } \\
\text { (max depth)* } \\
\text { (m) }\end{array}$} & \multirow{2}{*}{$\begin{array}{l}\text { TDS }^{\& \#} \\
\text { (ppm) }\end{array}$} & \multirow{2}{*}{$\begin{array}{l}\text { Chlorophyll- } \\
a^{\#} \\
\left(\mu \mathrm{g} \mathrm{L}^{-1}\right)\end{array}$} & \multirow{2}{*}{$\begin{array}{l}\text { Secchi disc } \\
\text { visibility } \\
(\mathrm{cm})\end{array}$} & \multicolumn{2}{|l|}{$\mathrm{O}_{2}$ dissolved } \\
\hline & $\Phi(\mathrm{N})$ & $\lambda(\mathrm{E})$ & & & & & & $\left(\mu \mathrm{mol} \mathrm{L}{ }^{-1}\right)$ & $(\%)$ \\
\hline Resko & $54^{\circ} 08^{\prime} 32^{\prime \prime}$ & $15^{\circ} 22^{\prime} 37^{\prime \prime}$ & 686.6 & $1.3(2.5)$ & $1788-4243$ & $17.2-175.3$ & $28-58$ & $0.21-0.38$ & $61-118$ \\
\hline Jamno & $54^{\circ} 16^{\prime} 24^{\prime}$ & $16^{\circ} 09^{\prime} 02^{\prime \prime}$ & 2239.6 & $1.4(3.9)$ & $178-319$ & $52.6-192.5$ & $23-38$ & $0.14-0.44$ & 51-138 \\
\hline Bukowo & $54^{\circ} 20^{\prime} 35^{\prime \prime}$ & $16^{\circ} 16^{\prime} 43^{\prime \prime}$ & 1747.4 & $1.8(2.8)$ & $1333-2107$ & $75.4-301.2$ & $33-65$ & $0.14-0.47$ & $53-136$ \\
\hline Wicko & $54^{\circ} 32^{\prime} 22^{\prime \prime}$ & $16^{\circ} 37^{\prime} 08^{\prime \prime}$ & 1059.0 & $2.0(6.1)$ & $132-236$ & $36.5-196.8$ & $32-44$ & $0.18-0.43$ & $67-132$ \\
\hline Kopań & $54^{\circ} 29^{\prime} 04^{\prime \prime}$ & $15^{\circ} 27^{\prime} 02^{\prime \prime}$ & 789.7 & $1.9(3.9)$ & $301-2758$ & $9.6-91.4$ & $32-48$ & $0.17-0.47$ & $65-147$ \\
\hline Gardno & $54^{\circ} 39^{\prime} 14^{\prime \prime}$ & $17^{\circ} 06^{\prime} 43^{\prime \prime}$ & 2469.0 & $1.5(2.6)$ & $166-1140$ & 67.6-194.5 & $22-41$ & $0.25-0.47$ & $82-141$ \\
\hline Łebsko & $54^{\circ} 42^{\prime} 22^{\prime \prime}$ & $17^{\circ} 23^{\prime} 01^{\prime \prime}$ & 7142.0 & $1.5(6.3)$ & $342-5542$ & $44.9-130.7$ & $29-110$ & $0.18-0.43$ & $61-165$ \\
\hline
\end{tabular}

$\Phi$ latitude

$\lambda$ longitude

* Data from Jańczak (1997)

\& TDS total dissolved solids (salinity)

\# Measurements made between 05.2013 and 10.2014

solids (TDS)) ranged from 132 to $5542 \mathrm{ppm}$, but the majority of observations had TDS $<1000 \mathrm{ppm}$. The coastal lakes have high biological productivity, indicated by high chlorophyll- $a$ and low Secchi disc visibility (Table 1) throughout the study period.

\section{Sampling}

The lake sediment gas was sampled every 2-3 months between May 2013 and October 2014. In each lake, there were 2-6 sample stations (Fig. 1) located in different parts of the lakes displaying differences in salinity, water depth, macrophyte cover, and wind fetch (and thus wave action). The lowest salinity (TDS between 132 and $250 \mathrm{ppm}$ ) occurred throughout Lake Wicko and Lake Jamno, while Lake Resko and Lake Łebsko had the highest salinity (TDS $>1000$ ppm). The water depth varied between c.a. $50 \mathrm{~cm}$ in Lake Kopań (site KOP1 and KOP4), Lake Wicko (WIC1), and Lake Jamno (JAM1) to $>300 \mathrm{~cm}$ in Lake Łebsko (LEB5) and Lake Wicko (WIC8). Dense macrophyte cover was developed in western parts of Lake Wicko (WIC1), Lake Kopań (KOP1, KOP4), and Lake Bukowo (BUK6). WIC1, KOP1, KOP4 and BUK6 were located in wind-protected embayments and had low wind wave action. The highest wind wave action occurred in the sites located in the eastern (upwind) parts of the lakes studied (JAM8, BUK8, WIC8, GAR2, LEB5, and LEB4). The sediment gas was sampled from an anchored boat. The gas was released by gentle agitation of the sediments with a hammer suspended from a string. Bubbles escaping from the sediment were trapped at the lake surface with a funnel and by displacement into $0.5 \mathrm{~L}$ dark glass bottles filled prior to sampling with lake water. After sampling, some water $(\sim 20-25 \mathrm{~mL})$ was left in the neck of the sealed bottle to minimize gas escape. The surface $5 \mathrm{~cm}$ layer of lake sediments was sampled using a gravity sampler (Limnos). The physical-chemical properties of lake waters (temperature, TDS, $\mathrm{pH}$, Red-ox potential, dissolved $\mathrm{O}_{2}$ ) were determined in situ with HI 9828 (Hannah Instruments) and HQD40 (Hach-Lange) probes. Measurements were made at the lake surfaces $(5-10 \mathrm{~cm}$ below the water surface), near-bottom $(5-10 \mathrm{~cm}$ above the lake bottom), and in sediment pore waters (uppermost $5-10 \mathrm{~cm}$ of sediments). The Redox potential measured in situ was corrected with the reference potential of the sensor to obtain the potential of a standard hydrogen electrode (Eh). Water depth was measured with a Humminbird 150 sonar. Wind action was determined only approximately in terms of wind fetch (F) and the depth of water mixed layer $\left(\mathrm{D}_{\mathrm{WML}}\right)$. The higher $\mathrm{F}$ and $\mathrm{D}_{\mathrm{WML}}$, the deeper wave motion in lake water column. For calculating $\mathrm{F}$ and $\mathrm{D}_{\mathrm{WML}}$ we used formulae proposed by Douglas and Rippey (2000).

Analytical procedures

The bulk composition of lake sediments was analyzed using lyophilized and powdered samples, as were the stable $\mathrm{C}$ isotope ratio measurements of TOC (total 
organic carbon, $\delta^{13} \mathrm{C}_{\mathrm{TOC}}$ ). The total carbon (TC), total nitrogen (TN), and total sulfur (TS) contents were determined by an elemental analyser (EA) (Elementar VarioMax CNS). TOC was also determined by an EA, except that prior to the measurement carbonates were removed by $1 \mathrm{M} \mathrm{HCl}$. The total inorganic carbon (TIC) was calculated as TIC [wt\%] = TC-TOC. The TOC/N was calculated on a molar (at./at.) basis. The samples were analysed in duplicate. Quality control was performed using certified reference materials for peaty (BN225497), chalky (BN230229), and sandy soils (BN230227) (Elementar).

For $\delta^{13} \mathrm{C}_{\mathrm{TOC}}$, the carbonate fraction was removed beforehand with $10 \% \mathrm{HCl}$ and rinsed with water until $\mathrm{pH}$ 7. Carbon isotope ratio analyses of TOC were performed with a Flash EA 2000 connected online to a ThermoFinnigan Delta V Plus mass spectrometer. All carbon isotope ratios are reported in the usual $\delta$-notation $\left(\delta^{13} \mathrm{C}_{\mathrm{TOC}}\right)$ relative to Vienna Pee Dee Belemnite (VPDB). The accuracy and reproducibility of the analyses were checked by replicate analyses of laboratory standards calibrated to international standards USGS 40 and 41 . The $\delta^{13} \mathrm{C}_{\mathrm{TOC}}$ reproducibility was $\pm 0.2 \%$.

The molecular composition of hydrocarbons (HC) in the sediment gas bubbles was analysed with a Fissons Instrument GC 8160 gas chromatograph with a flame ionization detector (FID-GC). The volumetric concentrations (vol\%) of $\mathrm{CH}_{4}, \mathrm{CO}_{2}, \mathrm{O}_{2}, \mathrm{~N}_{2}$, and higher hydrocarbons $\left(\mathrm{HHC} \approx \sum \mathrm{C}_{2+}\right.$ ) were measured using a Carlo Erba Instruments GC 6300 gas chromatograph. Details of the procedure are given by Sechman et al. (2009). The precision of concentration measurements was equal: $\mathrm{HC} \pm 0.1 \mathrm{ppm} ; \mathrm{CO}_{2}: \pm 0.01 \mathrm{vol} \% ; \mathrm{O}_{2}: \pm 0.02 \mathrm{vol} \%$ for concentration $<5 \mathrm{vol} \%$ and \pm 0.1 vol $\%$ for concentration $>5 \mathrm{vol} \%$; and $\mathrm{N}_{2}: \pm 0.05 \mathrm{vol} \%$ for concentration $<10 \mathrm{vol} \%$ and $\pm 0.1 \mathrm{vol} \%$ for concentration $>10 \mathrm{vol} \%$. The $\mathrm{C}_{\mathrm{HC}}$ (Bernard parameter) and $\mathrm{CO}_{2}-\mathrm{CH}_{4}$ index (CDMI), used to decipher the origin of sediment gases (Bernard et al. 1978; Kotarba and Nagao 2015), were calculated as follows:

$C_{H C}=\frac{C_{4}}{\left(C_{2} H_{6}+C_{3} H_{8}\right)}$

$\mathrm{CDMI}(\%)=\frac{\mathrm{CO}_{2}}{\left(\mathrm{CO}_{2}+\mathrm{CH}_{4}\right)} \times 100$

where $\mathrm{CH}_{4}, \mathrm{C}_{2} \mathrm{H}_{6}, \mathrm{C}_{3} \mathrm{H}_{8}$, and $\mathrm{CO}_{2}$ denominate volumetric percentages of the gases (Kotarba and Nagao 2015).
$\mathrm{CH}_{4}$ and $\mathrm{CO}_{2}$ were isolated chromatographically for carbon and hydrogen isotope analyses. $\mathrm{CH}_{4}$ was combusted over hot $\mathrm{CuO}\left(850{ }^{\circ} \mathrm{C}\right)$ and converted to $\mathrm{CO}_{2}$. Stable isotope analyses were performed using Finnigan Delta Plus and Micromass VG Optima isotope ratio mass spectrometers (IRMS). The stable $\mathrm{C}$ isotope data are expressed in the $\delta$-notation $\left(\delta^{13} \mathrm{C}\right.$, \%o) relative to VPDB, taking the reference NBS-22 (oil) to be $-30.03 \%$. The stable $\mathrm{H}$ isotope data are reported in $\delta$-notation $\left(\delta^{2} \mathrm{H}, \%\right.$ ) relative to the international standard, VSMOW (Vienna-standard mean ocean water $=0.0 \%$ ), and linearized to standard light arctic precipitation (SLAP) as recommended by Coplen (2011). Molecular $\mathrm{N}_{2}$ was separated chromatographically for stable $\mathrm{N}$ isotope analyses and was measured by on-line IRMS. The results of stable $\mathrm{N}$ isotope analyses were presented in $\delta$-notation $\left(\delta^{15} \mathrm{~N}, \%\right.$ o) relative to the air $\mathrm{N}_{2}$ standard. Analytical precision is estimated to be $\pm 0.2 \%$ or $\mathrm{C}$, $\pm 3 \%$ for $\mathrm{H}_{2}$, and $\pm 0.4 \%$ or $\mathrm{N}_{2}$.

Statistical calculations were performed with Statistica 12 (StatSoft, Inc. 2014).

\section{Results}

Sediments

The sediments containing $\mathrm{CH}_{4}$ and $\mathrm{CO}_{2}$ bubbles had TOC contents from 7.5 to $21.1 \mathrm{wt} \%$, and the TIC was between 0.4 and $4.9 \mathrm{wt} \%$. The contents of TS were 1.0-2.6 wt \% . The molar TOC/TN was between 7.9 and 10.0 (Table 2). The stable $\mathrm{C}$ isotope signatures in bulk organic carbon $\left(\delta^{13} \mathrm{C}_{\mathrm{TOC}}\right)$ varied from -29.1 to $-26.6 \%$, except for Lake Kopań which displayed less negative values of -24.7 and $-24.4 \%$ (Table 2). There were appreciable differences in the sediment composition between the lakes and within each lake. The highest TOC values were obtained in Lake Wicko. Lake Gardno was distinguished by the highest TIC and the lowest TOC contents. Throughout the study period, the surface sediments were anoxic (dissolved $\mathrm{O}_{2}=0 \mu \mathrm{mol} \mathrm{L}{ }^{-1}$ ) and displayed appreciable seasonal changes in Eh. During cold periods (Nov. 2013-Feb. 2014) the Eh was positive (+8 to $+181 \mathrm{mV}$ ) at all but one study site, while during the warm season (Aug. 2014) Eh dropped to negative values $(-32$ to $-255 \mathrm{mV})$. 
Table 2 Bulk chemical composition of surface sediments of the lakes studied
TN total organic N, TOC total organic $\mathrm{C}$, TIC total inorganic $\mathrm{C}, T S$ total $\mathrm{S}$

\begin{tabular}{llllllll}
\hline Lake & Study site & $\begin{array}{l}\text { TN } \\
\text { wt\% }\end{array}$ & TOC & TIC & TS & $\begin{array}{l}\text { TOC/N (at./ } \\
\text { at.) }\end{array}$ & $\begin{array}{l}\delta^{13} \mathrm{C}_{\mathrm{TOC}} \\
\% \text { VPDB }\end{array}$ \\
\hline Resko (LR) & RP 5 & 1.7 & 14.5 & 0.6 & 2.1 & 9.8 & -29.0 \\
Jamno (LJ) & JAM 1 & 1.9 & 15.7 & 1.6 & 1.6 & 9.7 & -27.9 \\
& JAM 5 & 1.5 & 12.5 & 0.9 & 1.3 & 10.0 & -28.0 \\
& JAM 6 & 1.0 & 7.5 & 0.7 & 1.2 & 8.9 & -28.5 \\
Bukowo (LB) & BUK 3 & 1.2 & 9.8 & 0.6 & 1.9 & 9.3 & -28.9 \\
& BUK 6 & 2.2 & 17.1 & 0.4 & 2.4 & 9.0 & -28.2 \\
Kopań (LK) & KUK 8 & 2.2 & 17.2 & 0.6 & 2.2 & 9.2 & -29.0 \\
& KOP 1 & 2.3 & 18.8 & 2.6 & 1.4 & 9.5 & -24.4 \\
Wicko (LW) & KOP 4 & 2.1 & 17.3 & 2.6 & 2.1 & 9.5 & -24.7 \\
& WIC 1 & 2.9 & 21.1 & 1.7 & 1.8 & 8.5 & -28.2 \\
& WIC 2 & 2.6 & 17.0 & 4.3 & 1.2 & 7.9 & -28.1 \\
& WIC 8 & 3.1 & 20.6 & 3.2 & 1.4 & 7.9 & -29.1 \\
Gardno (LG) & GAR 2 & 1.2 & 8.7 & 4.2 & 1.0 & 8.3 & -26.6 \\
& GAR 3 & 1.3 & 9.5 & 4.4 & 1.2 & 8.5 & -26.7 \\
& GAR 4 & 1.1 & 9.45 & 4.9 & 1.5 & 9.7 & -27.0 \\
& LEB 4 & 1.6 & 17.3 & 2.6 & 1.4 & 9.5 & -27.7 \\
Łebsko (LL) & LEB 5 & 1.7 & 13.6 & 1.1 & 1.5 & 9.6 & -27.6 \\
& LEB 7 & 1.2 & 14.7 & 1.7 & 2.6 & 9.9 & -28.1 \\
\hline
\end{tabular}

CDMI was different in vegetated and non-vegetated sites (Fig. 3a). In the former the CDMI was higher (i.e. there was more $\mathrm{CO}_{2}$ in relation to $\mathrm{CH}_{4}-4.72$ on average) than in the latter (2.04 on average). The CDMI displayed a weak seasonal pattern, with a slight tendency to increase with increasing water temperatures (Fig. 3b).

The composition of $\mathrm{HC}$ (in terms of $\mathrm{C}_{\mathrm{HC}}$ ratio) displayed some spatial and temporal variation. The highest values of $\mathrm{C}_{\mathrm{HC}}$ occurred in Lake Wicko, and Lake Gardno, while the lowest values were obtained in Lake Resko and Jamno. The mean $\mathrm{C}_{\mathrm{HC}}$ showed overall (statistically insignificant) negative relationship to salinity (Fig. 4a) and temperature (Fig. 4b) i.e. the high values of $\mathrm{C}_{\mathrm{HC}}(>20,000)$ occurred at low salinity $(<2000 \mathrm{ppm})$ and low temperature $\left(<5^{\circ} \mathrm{C}\right)$.

Stable isotope composition of sediment gas

$\mathrm{N}_{2}$

The $\delta^{15} \mathrm{~N}_{2}$ signatures showed minor changes from -2.1 to $+1.7 \%$ o (see Table 3 in Appendix). The $\delta^{15} \mathrm{~N}_{2}$ showed differences between lakes. The highest values were measured in Lake Jamno, and Lake Gardno and the lowest in Lake Bukowo, and Lake Łebsko. 

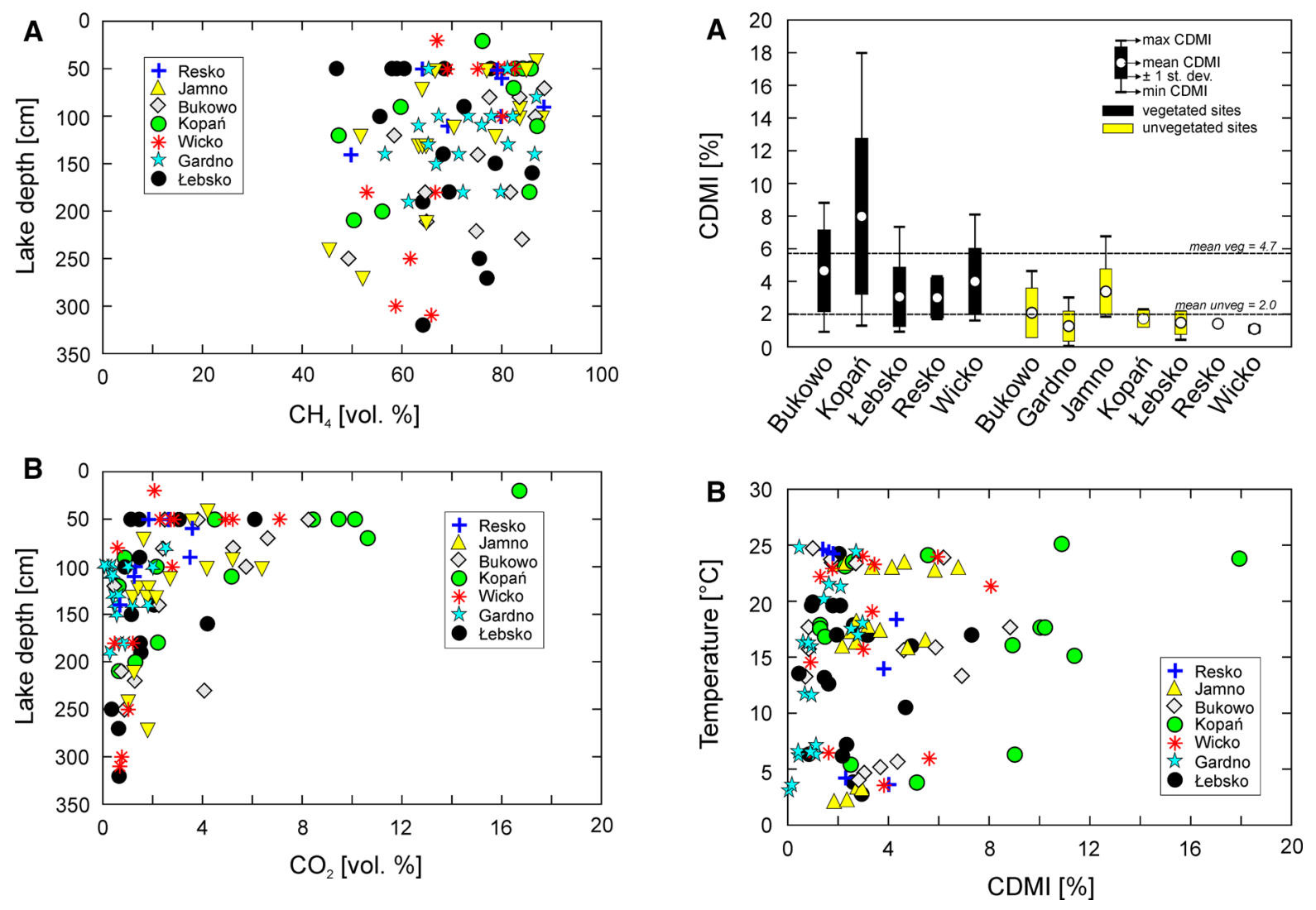

Fig. $2 \mathrm{CH}_{4}(\mathbf{A})$ and $\mathrm{CO}_{2}(\mathbf{B})$ concentrations versus lake water depth for the seven lakes studied. In most lakes, except for Lake Łebsko and Lake Gardno, there is an overall negative relationship between these parameters

$\mathrm{CO}_{2}$

The $\delta^{13} \mathrm{C}_{\mathrm{CO} 2}$ varied over a very broad range from -51.5 to $+6.0 \%$ (see Table 3 in Appendix), with a slight tendency towards higher values during colder seasons (Fig. 5). There was also a clear increasing trend in $\delta^{13} \mathrm{C}_{\mathrm{CO} 2}$ values with decreasing water depth (except for Lake Łebsko) (Fig. 5) and increasing $\mathrm{CO}_{2}$ concentrations (Fig. 6). The $\delta^{13} \mathrm{C}_{\mathrm{CO} 2}$ values obtained in vegetated sites were higher than in non-vegetated sites (Fig. 7).

\section{$\mathrm{CH}_{4}$}

The $\delta^{13} \mathrm{C}_{\mathrm{CH} 4}$ values ranged from -77.9 to $-55.1 \%$ (see Table 3 in Appendix) and showed differences between lakes (Fig. 5). The highest mean $\delta^{13} \mathrm{C}_{\mathrm{CH} 4}$ values were obtained in Lake Kopan, while the lowest were measured in Lake Bukowo, and Lake Resko. The

Fig. 3 The $\mathrm{CO}_{2}-\mathrm{CH}_{4}$ index (CDMI) differences between vegetated and unvegetated sites (A) and the relationship between the CDMI values and lake water temperature $(\mathbf{B})$. The horizontal lines in A indicate average CDMI for vegetated and unvegetated sites (mean veg and mean unveg, respectively). Unvegetated sites in Lake Resko are represented by one measurement

mean $\delta^{13} \mathrm{C}_{\mathrm{CH} 4}$ revealed overall seasonality. A decrease in $\delta^{13} \mathrm{C}$ in $\mathrm{CH}_{4}$ occurred in warmer seasons $\left(\delta^{13} \mathrm{C}_{\mathrm{CH} 4}\right.$ for summer months was between -77.9 and $-55.4 \%$ ), while during autumn and winter the $\mathrm{CH}_{4}$ become isotopically heavier $\left(\delta^{13} \mathrm{C}_{\mathrm{CH} 4}\right.$ between -71.1 and $-57.4 \%$ ).

The $\delta^{13} \mathrm{C}_{\mathrm{CH} 4}$ showed changes within each lake. Except for Lake Łebsko and Lake Resko, spatial and temporal changes in $\delta^{13} \mathrm{C}_{\mathrm{CH} 4}$ were strongly related to the concentrations of $\mathrm{CH}_{4}$. The more abundant the $\mathrm{CH}_{4}$, the higher the $\delta^{13} \mathrm{C}_{\mathrm{CH} 4}$ signatures (the $\mathrm{r}$ values for this relationship are significant at $\mathrm{p}<0.01$ and range from 0.71 to 0.88 ). In addition, in most of the lakes studied (except for Lake Gardno and Łebsko) the $\delta^{13} \mathrm{C}_{\mathrm{CH} 4}$ revealed an overall negative relationship to water depth (Fig. 5), and the correlation coefficients for this relationship were between -0.52 and -0.85 

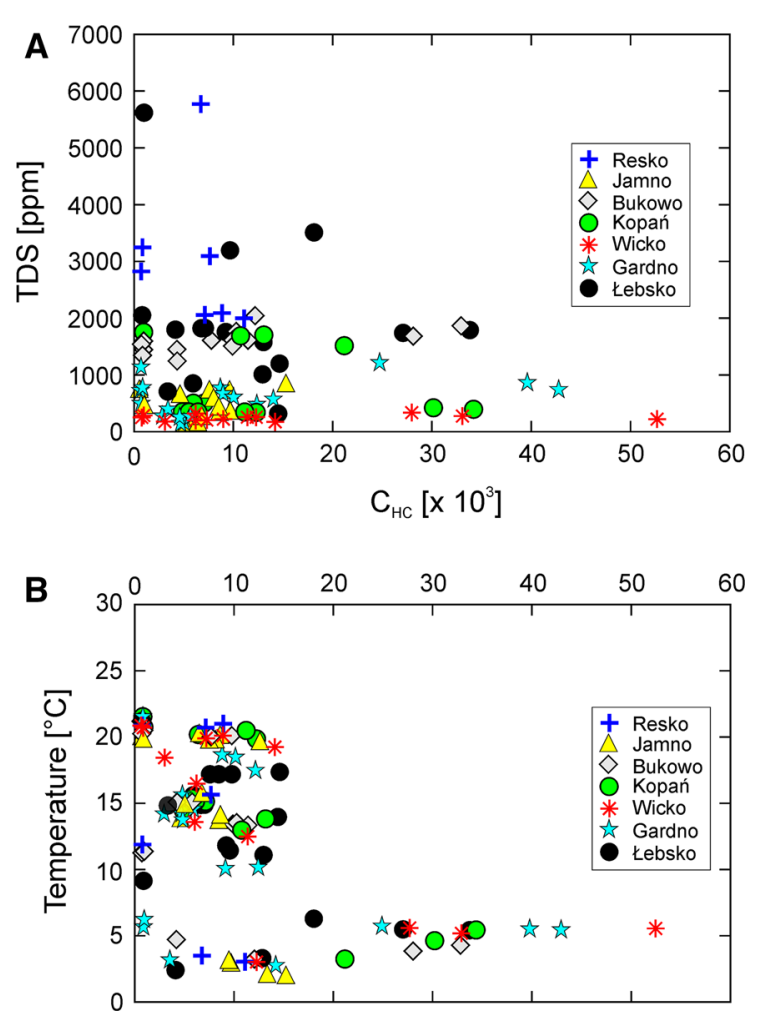

Fig. 4 Bernard index $\left(\mathrm{C}_{\mathrm{HC}}\right)$ versus lake water salinity (expressed as total dissolved solids, TDS) (A) and temperature (B). The $\mathrm{C}_{\mathrm{HC}}$ was low throughout major parts of the TDS and temperature ranges except for TDS $<2000 \mathrm{ppm}$ and temperatures $<5{ }^{\circ} \mathrm{C}$. At low salinity and temperature the $\mathrm{C}_{\mathrm{HC}}$ increased sharply

(at $\mathrm{p}<0.04$ ). We obtained differences between the $\delta^{13} \mathrm{C}_{\mathrm{CH} 4}$ signatures in vegetated and non-vegetated sites (Fig. 7): $-63.6 \%$ for vegetated sites and $-67.2 \%$ for unvegetated sites.

The $\delta^{2} \mathrm{H}_{\mathrm{CH} 4}$ values varied between -378 and $-261 \%$ (Fig. 8). There were no clear differences between the lakes.

\section{Discussion}

Factors affecting the concentration of $\mathrm{CH}_{4}, \mathrm{CO}_{2}$, $\mathrm{N}_{2}$, and $\mathrm{O}_{2}$ in sediment gas

The collected gas was enriched in $\mathrm{N}_{2}$ by up to $51 \%$, and contained appreciable amounts of $\mathrm{O}_{2}$ (up to $5.5 \%$ ). Furthermore, the $\delta^{15} \mathrm{~N}_{2}$ signatures were too high for $\mathrm{N}_{2}$ produced via denitrification, a highly fractionating process resulting in $\delta^{15} \mathrm{~N}_{2}$ between -40 and $-5 \%$
(Talbot 2001). Instead, the $\delta^{15} \mathrm{~N}_{2}$ values obtained were close to the values in atmospheric $\mathrm{N}_{2}$ (in which $\delta^{15} \mathrm{~N}_{2}$ is $\sim 0 \%$; Talbot 2001). $\mathrm{N}_{2}$ exchange between the atmosphere and water is accompanied by a very low fractionation (Talbot 2001), and consequently dissolved $\mathrm{N}_{2}$ preserves the $\delta^{15} \mathrm{~N}_{2}$ values of atmospheric $\mathrm{N}_{2}$. Hence, the $\delta^{15} \mathrm{~N}_{2}$ values obtained argued for an atmospheric origin of the $\mathrm{N}_{2}$ occurring in the gas from the sediments of the lakes studied. Anoxia of pore waters indicated that the $\mathrm{O}_{2}$ present in the sediment gas was unlikely to be derived from processes occurring within the sediments (e.g. photosynthesis). It seems therefore that both $\mathrm{N}_{2}$ and $\mathrm{O}_{2}$ invaded the sediment gas via three possible routes.

First, the macrophytes act as conduits for gas exchange between the sediment and the atmosphere (Makhov and Bazhin 1999; Chanton et al. 2005; Laanbroek 2010). Plant ventilation was invoked to explain the sediment gas composition in the White Oak River estuary (Chanton et al. 1989). Chanton et al. (1989) demonstrated that $\mathrm{N}_{2}$ and $\mathrm{CH}_{4}$ were strongly negatively correlated and that sediment gas from densely vegetated sites was clearly $\mathrm{N}_{2}$-enriched compared with "purely" microbial gas. Despite the fact, that in our study the sampling stations were located in both vegetated and non-vegetated parts of the coastal lakes, there were no differences in $\mathrm{N}_{2}$ concentrations between these sites. In addition, the $\delta^{15} \mathrm{~N}_{2}$ signatures from vegetated and non-vegetated sites were similar. In the former, $\delta^{15} \mathrm{~N}_{2}$ ranged between -1.3 and $0.7 \%$ ( $(-0.3 \%$ on average), while in the latter it ranged from -2.1 to $1.7 \%$ o $(-0.2 \%$ on average). Moreover, vegetated and non-vegetated sites had the same $\mathrm{O}_{2}$ distribution. These features indicated that the $\mathrm{N}_{2}$ and $\mathrm{O}_{2}$ concentrations were likely little affected by plant ventilation.

Second, $\mathrm{N}_{2}$ and $\mathrm{O}_{2}$ can be supplied to the sediments in the form of large bubbles entrapped by solid particles settling in aerated water after a storm (Boudreau 2012) and/or via diffusion from overlying aerated water (Chanton et al. 1989; Walter et al. 2008). These bubbles act as nucleation sites (heterogenous nucleation) for larger bubbles containing microbial gas. The $\mathrm{CH}_{4}$ and $\mathrm{CO}_{2}$ from methanogenesis are delivered to these initial bubbles via diffusion in the pore waters; and when the critical size of a bubble is achieved, ebullition commences. There are some data indicating that the sediments of coastal lakes are deeply mixed due to wind-induced turbulence. Woszczyk et al. (2014) established that in Lake 
Fig. 5 Stable $\mathrm{C}$ isotope composition of $\mathrm{CH}_{4}$ and $\mathrm{CO}_{2}$ in the lakes studied during different sampling campaigns and at different depth intervals. Lake water depth is indicated by grey dashed lines. The number attached to the lines

denominate the lake water depth in $\mathrm{cm}$. In Lake Łebsko there was no relationship between the stable isotope composition of gases and water depth, and therefore the depth lines were not shown. The grey numbers next to data points show the collection depth of outliers. Note that there is an overall tendency for $\delta^{13} \mathrm{C}_{\mathrm{CO} 2}$ and $\delta^{13} \mathrm{C}_{\mathrm{CH} 4}$ to increase with decreasing water depth. $\alpha_{\mathrm{c}}$ denominate apparent $\mathrm{C}$ isotope fractionation factors (according to Whiticar 1999). Stable C isotope composition indicate that the $\mathrm{CH}_{4}$ is predominantly produced via acetoclastic methanogenesis (AM) with only minor contribution of hydrogenotrophic

methanogenesis (HM). In a few sites the $\mathrm{CH}_{4}$ is prone to oxidation (OX). The colors indicate seasons: whitewinter, green-spring, red-summer, yellowautumn
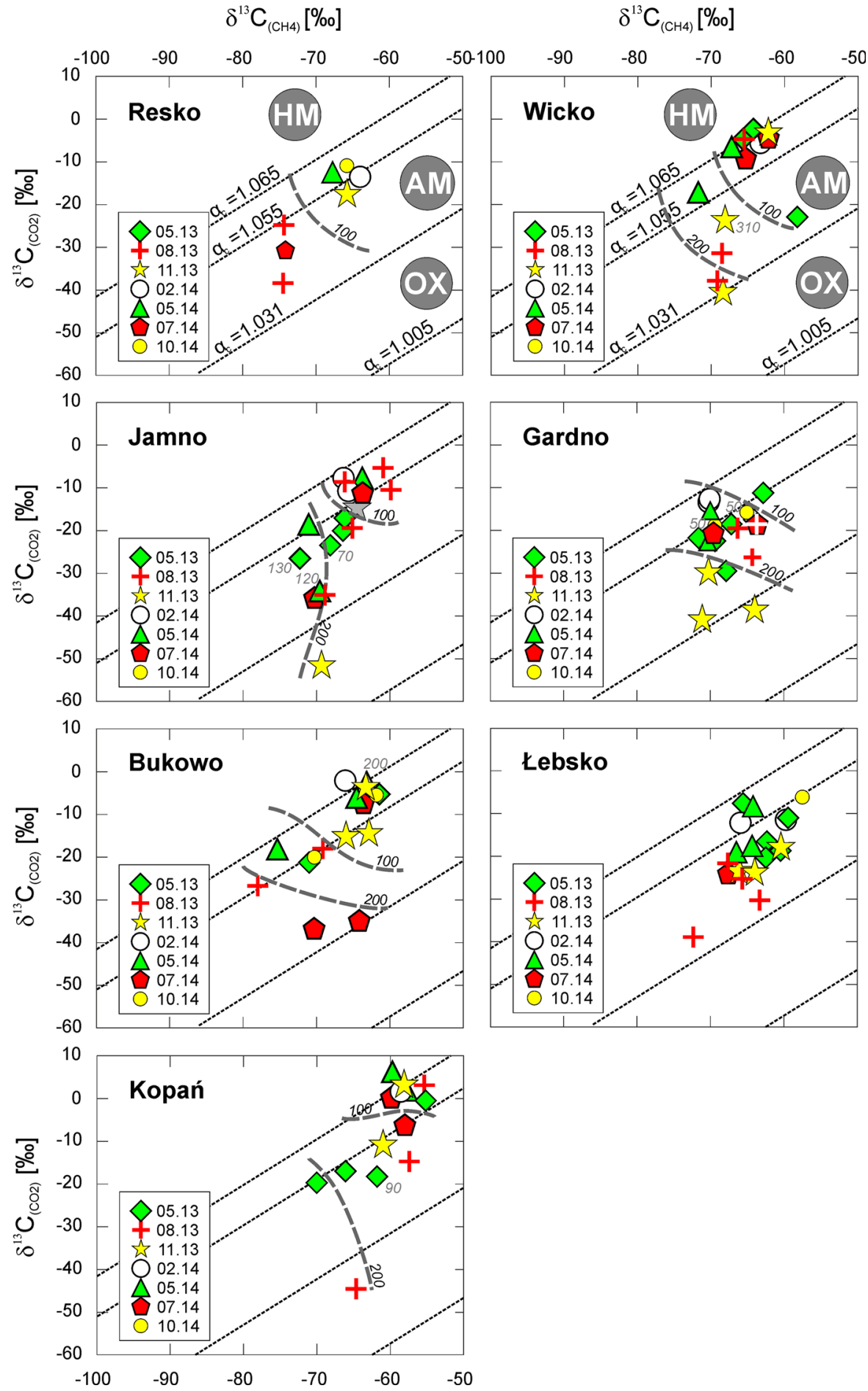

Sarbsko (located $3 \mathrm{~km}$ east of Lake Łebsko) the mixing was up to $50 \mathrm{~cm}$ depth. Unpublished data $\left({ }^{210} \mathrm{~Pb},{ }^{137} \mathrm{Cs}\right.$ and ${ }^{7} \mathrm{Be}$ distributions) from Lake Gardno, Lake Bukowo and Lake Resko showed mixing depth between 13 and $22 \mathrm{~cm}$. These values supported the hypothesis on the potential effect of storm redeposition on air bubble entrapment in the sediments. 


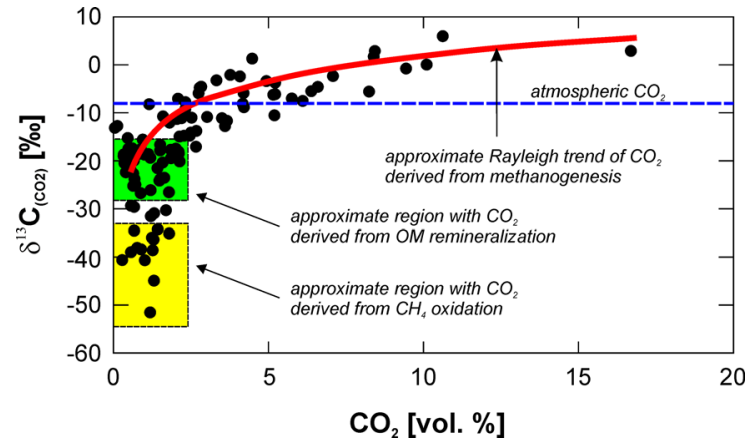

Fig. 6 Stable $\mathrm{C}$ isotope signatures of $\mathrm{CO}_{2}\left(\delta^{13} \mathrm{C}_{\mathrm{CO} 2}\right)$ versus concentration of $\mathrm{CO}_{2}$ in the sediment gas. There is a clear negative relationship between $\delta^{13} \mathrm{C}_{\mathrm{CO} 2}$ and the $\mathrm{CO}_{2}$ concentration, explained by $\mathrm{CO}_{2}$ removal from rising bubbles owing to dissolution and gas exchange. The more strongly ${ }^{13} \mathrm{C}$-depleted $\delta^{13} \mathrm{C}_{\mathrm{CO} 2}$ values can only be explained by methanotrophy. The ${ }^{13} \mathrm{C}$-enriched $\delta^{13} \mathrm{C}_{\mathrm{CO} 2}$ values extending to $+6 \%$ were obtained in shallowest parts of the lakes and resulted from methanogenesis. The $\delta^{13} \mathrm{C}_{\mathrm{CO} 2}$ values centered around $-25 \%$ can be derived from a variety of sources and processes, including the respiration of $\mathrm{CO}_{2}$ from organic matter

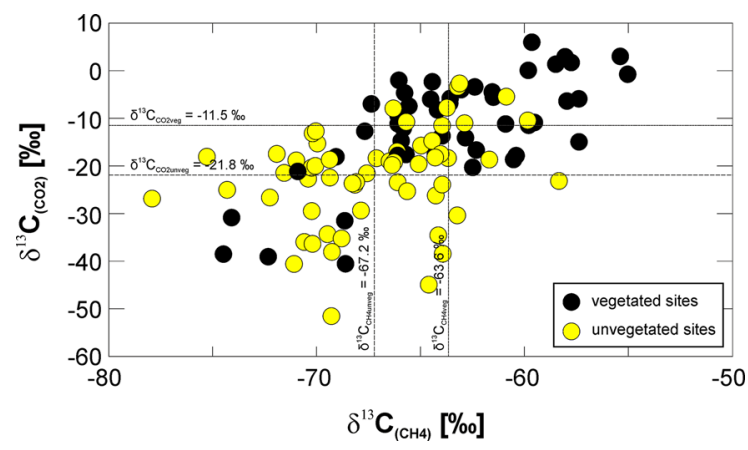

Fig. 7 Stable $\mathrm{C}$ isotope signatures of $\mathrm{CO}_{2}\left(\delta^{13} \mathrm{C}_{\mathrm{CO} 2}\right)$ and $\mathrm{CH}_{4}$ $\left(\delta^{13} \mathrm{C}_{\mathrm{CH} 4}\right)$ in vegetated and non-vegetated sites. The former display higher $\delta^{13} \mathrm{C}_{\mathrm{CO} 2}$ and $\delta^{13} \mathrm{C}_{\mathrm{CH} 4}$ signatures, which provides evidence for stable $\mathrm{C}$ isotope fractionation accompanying bioventilation. Mean $\delta^{13} \mathrm{C}_{\mathrm{CO} 2}$ and $\delta^{13} \mathrm{C}_{\mathrm{CH} 4}$ for vegetated $\left(\delta^{13} \mathrm{C}_{\mathrm{CO} 2 \mathrm{veg}} ; \delta^{13} \mathrm{C}_{\mathrm{CH} 4 \mathrm{veg}}\right)$ and unvegetated $\left(\delta^{13} \mathrm{C}_{\mathrm{CO} 2 \text { unveg }} ; \delta^{13-}\right.$ $\mathrm{C}_{\mathrm{CH} 4 \text { unveg }}$ ) sites are shown by horizontal and vertical dashed lines, respectively

Third, the $\mathrm{N}_{2}$ and $\mathrm{O}_{2}$ can invade ascending gas bubbles in a lake water column due to exchange between $\mathrm{CH}_{4} / \mathrm{CO}_{2}$ and $\mathrm{N}_{2} / \mathrm{O}_{2}$ dissolved in the column (Leifer and Patro 2002; McGinnis et al. 2006; Ostrovsky et al. 2008; Yamamoto et al. 2009; Del Sontro et al. 2010; McGinnis et al. 2011). $\mathrm{N}_{2}$ and $\mathrm{O}_{2}$ build up in lake waters due to dissolution of air bubbles forced by breaking wind waves, Langmuir currents, and rain drop impacts (Chiba and Baschek 2010; Liang et al.

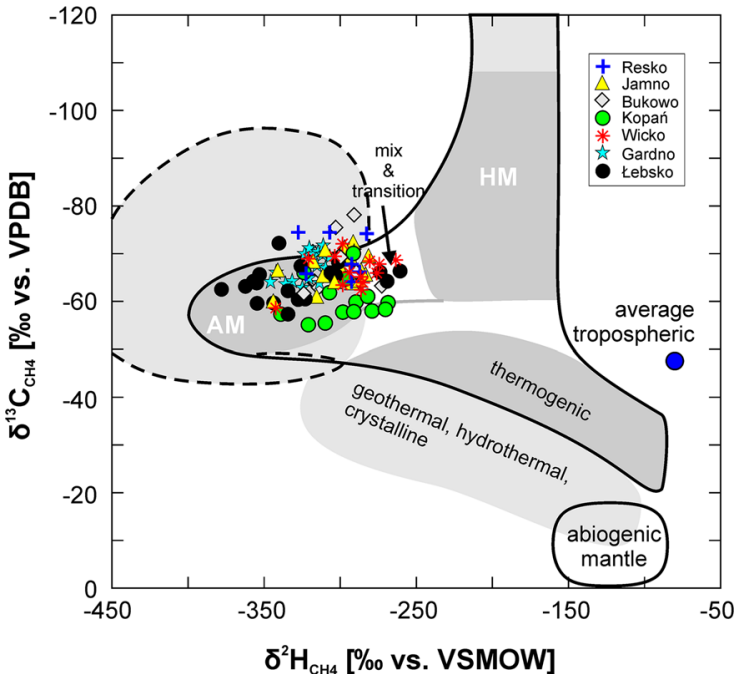

Fig. 8 Combination of $\delta^{13} \mathrm{C}_{\mathrm{CH} 4}$ and $\delta^{2} \mathrm{H}_{\mathrm{CH} 4}$ to delineate $\mathrm{CH}_{4}$ sources. The $\delta^{2} \mathrm{H}_{\mathrm{CH} 4}$ and $\delta^{13} \mathrm{C}_{\mathrm{CH} 4}$ indicative of acetoclastic methanogenesis (AM). Genetic fields after Whiticar (1999). $A M$ acetoclastic methanogenesis, HM hydrogenotrophic methanogenesis

2011), and the concentration (supersaturation) of these gases is positively related to wind speed (Nakayama et al. 2002). At high wind speeds $\left(>15 \mathrm{~m} \mathrm{~s}^{-1}\right)$ the airwater gas exchange is predominantly via bubbles (Chiba and Baschek 2010). Coastal lakes on the Polish Baltic coast reveal very high vulnerability to wind mixing. The Baltic coast is the windiest part of Poland (Lorenc 1996), and in 2013/2014 there were between 8 (meteorological station in Koszalin; Fig. 1) and 105-111 days (meteorological station in Łeba and Ustka, respectively; Fig. 1) with a strong wind (with speed $\mathrm{v}_{\mathrm{w}}>10 \mathrm{~m} \mathrm{~s}^{-1}$ ). In addition, due to the parallel orientation of coastal lakes to the predominant and the strongest W-SW winds, the wind fetch $(\mathrm{F})$ and the depth of water mixed layer $\left(\mathrm{D}_{\mathrm{WML}}\right)$ for the lakes were both high. The F varied between $0.9 \mathrm{~km}$ for RP5 and $5.9 \mathrm{~km}$ for LEB4, and the $\mathrm{D}_{\mathrm{WML}}$ ranged from $0.5-2.8 \mathrm{~m}\left(\right.$ at $\left.\mathrm{v}_{\mathrm{w}}=1 \mathrm{~m} \mathrm{~s}^{-1}\right)$ to $2-6 \mathrm{~m}\left(\right.$ at $\mathrm{v}_{\mathrm{w}}=10$ $\mathrm{m} \mathrm{s}^{-1}$ ) which was higher than the water depth in most of the sampling stations. The obtained $\mathrm{D}_{\mathrm{WML}}$ values indicated that the whole water column in the lakes was mixed by wind.

The air entrapped in water can be transported to appreciable depths in the lake water column, sometimes to more than $20 \mathrm{~m}$ below the water surface (Farmer et al. 1993). A rough estimation of the depth of bubble entrainment by wind waves in the distal (eastern) parts 
of the lakes studied, according to the formula by Chiba and Baschek (2010), showed that during strong winds the bubbles could be drawn to c.a. $40 \mathrm{~cm}$ below the water surface. This value could be even higher when the Langmuir circulation was active (Langmuir circulation was observed in the lakes during field campaigns) because it is known to entrain air bubbles even deeper than wind waves (Liang et al. 2011). It is thus likely that in some parts of the coastal lakes there is a very deep air bubble penetration in the water.

The aeration of water during vigorous mixing leads to supersaturation with respect to $\mathrm{N}_{2}$ and $\mathrm{O}_{2}$. According to Liang et al. (2011), the degree of supersaturation is inversely related to the solubility of the gases. Therefore $\mathrm{N}_{2}$ tends to be more supersaturated than $\mathrm{O}_{2}$ and the $\mathrm{N}_{2} / \mathrm{O}_{2}$ ratio for equilibrium concentrations of both gases in water is c.a. 1.8-1.9 (at temperatures between 0 and $20^{\circ} \mathrm{C}$ and $0 \%$ salinity) (Weiss 1970). However, the values obtained for $\mathrm{N}_{2} / \mathrm{O}_{2}$ of 3-7000 are much higher than the equilibrium. Taking into account that some $\mathrm{O}_{2}$ is added to lake waters by the photosynthesis of phytoplankton (Ford et al. 2002; Walter et al. 2008), it appears that $\mathrm{O}_{2}$ is significantly underrepresented, particularly during summer. Indeed, the mean seasonal values of $\mathrm{N}_{2} / \mathrm{O}_{2}$ displayed a positive correlation to lake water temperature $(\mathrm{r}=0.70, \mathrm{n}=7$, $\mathrm{p}<0.08$ ), and during the summer there were the lowest concentrations of dissolved $\mathrm{O}_{2}$ in the lake waters. A plausible reason for $\mathrm{O}_{2}$ depletion might be the enhanced oxidation of organic matter (Schubert et al. 2010; Woszczyk et al. 2011).

It seems that gas exchange between bubbles and surrounding water strongly affected the molecular composition of the sediment gas from the coastal lakes. This influence explains the strong negative correlation between $\mathrm{CH}_{4}$ and $\mathrm{N}_{2} \quad(\mathrm{r}=-0.98$, $\mathrm{n}=114, \mathrm{p}<0.001$ ), as well as the overall negative relationship between the $\mathrm{CH}_{4}$ or $\mathrm{CO}_{2}$ and water depth observed in most of the lakes studied (Fig. 2). The greater the water depth, the longer the exposure of bubbles to highly aerated water and the higher the loss of the original gas composition.

The relationship between lake water depth and $\mathrm{CO}_{2}$ concentrations is stronger than the relationship between depth and $\mathrm{CH}_{4}$ concentrations (Fig. 2), which can be explained using the model by McGinnis et al. (2011). These authors claimed that $\mathrm{CO}_{2}$ "lifetime" in rising bubbles is very short compared with $\mathrm{CH}_{4}$ due to rapid dissolution of the former. Solubility of $\mathrm{CO}_{2}$ in water is c.a. 24 times higher than $\mathrm{CH}_{4}$ (Yamamoto et al. 1976), and consequently the concentration of $\mathrm{CO}_{2}$ in the bubbles decreases more rapidly than $\mathrm{CH}_{4}$ over the same distance in the water column.

However, the amount of $\mathrm{CH}_{4}$ exchanged seems surprisingly high in such shallow water bodies. Assuming an initial $0 \%$ contents of $\mathrm{N}_{2}$ and $\mathrm{O}_{2}$ and a predominance of $\mathrm{CH}_{4}$ and $\mathrm{CO}_{2}$ in the sediment gas, the fraction of lost $\mathrm{CH}_{4} / \mathrm{CO}_{2}$ varies between 10 and $67 \%$ (26\% on average). Despite $30 \%$ bubble $\mathrm{CH}_{4}$ dissolution being reported from Lake Wohlen (Switzerland), a shallow (10 $\mathrm{m}$ on average) reservoir lake (DelSontro et al. 2010), up to $67 \% \mathrm{CH}_{4}$ loss in coastal lakes seems high in relation to the depth of the sampling stations (maximum $3 \mathrm{~m}$ ). On the basis of the model proposed by McGinnis et al. (2006), losses of $\mathrm{CH}_{4}$ are strongly dependent on the initial bubble size and the release depth. In our study we were unable to measure bubble diameters. However, for typical bubbles, 6-10 $\mathrm{mm}$ in diameter (McGinnis et al. 2006; Ostrovsky et al. 2008; Yamamoto et al. 2009), a trajectory 10-30 m long is required to cause such a depletion in $\mathrm{CH}_{4}$. On the other hand, for bubbles $20 \mathrm{~mm}$ in diameter, reported as being representative of gassy sediments (Haeckel et al. 2007), a dissolution of $10-67 \% \mathrm{CH}_{4}$ would occur at water depths between ca. 20 and $150 \mathrm{~m}$.

There are different possible explanations for the high loss of $\mathrm{CH}_{4}$ from the bubbles collected in shallow coastal lakes. It seems that the dissolution of bubbles is enhanced by the low concentrations of dissolved $\mathrm{CH}_{4}$ $\left(\mathrm{CH}_{4 \text { diss }}\right.$ ) in lake water (Yamamoto et al. 2009). In the lakes studied, the concentrations of $\mathrm{CH}_{4 \text { diss }}$ vary from 0.024 to $3.770 \mu \mathrm{mol} \mathrm{L}{ }^{-1}\left(0.495 \mu \mathrm{mol} \mathrm{L}^{-1}\right.$ on average) (unpubl. data) which is rather low compared with anoxic bottom waters of productive lakes where the $\mathrm{CH}_{4 \text { diss }}$ can be as high as several hundred $\mu \mathrm{mol} \mathrm{L}-1$ (Liu et al. 1996; Juutinen et al. 2008; Schubert et al. 2010). Moreover, the high $\mathrm{CH}_{4}$ loss may be triggered by the supersaturation with respect to $\mathrm{N}_{2}$ and $\mathrm{O}_{2}$ in intensely wind-agitated surface waters (Nakayama et al. 2002). In the seven coastal lakes studied, the saturation of $\mathrm{O}_{2}$ can be as high as $165 \%$ (Table 1). The concentrations of $\mathrm{CH}_{4}$ in sediment gas can be modified by the rate of ebullition, which is water depthdependent. Engle and Melack (2000), Liikanen et al. (2003), Kankaala et al. (2004), and Boudreau (2012) suggested enhancement of $\mathrm{CH}_{4}$ ebullition under low hydrostatic pressure (i.e. in shallow waters). In turn, the intensity of bubble release is known to control the 
$\mathrm{CH}_{4} / \mathrm{N}_{2}$ ratio. Chanton et al. (1989) and Walter et al. (2008) showed that intense ebullition removes $\mathrm{N}_{2}$ from pore waters and results in higher $\mathrm{CH}_{4} / \mathrm{N}_{2}$ ratios in sediment gas. In some of the coastal lakes studied, there is an overall negative relationship between $\mathrm{CH}_{4} / \mathrm{N}_{2}$ and water depth (LW r $=-0.62, \mathrm{n}=13, \mathrm{p}<0.03$; LK $\mathrm{r}=-0.62, \mathrm{n}=14, \mathrm{p}<0.02 ; \mathrm{LJ} \mathrm{r}=-0.45, \mathrm{n}=17$, $\mathrm{p}<0.07$ and LB $\mathrm{r}=-0.59, \mathrm{n}=15, \mathrm{p}<0.03)$, arguing for a more intense ebullition in the shallowest parts of these lakes. Chanton et al. (1989) and Walter et al. (2008) used the $\mathrm{CH}_{4} / \mathrm{N}_{2}$ ratio to document spatial and temporal changes in ebullition rate. Ebullition usually intensifies during summer (Makhov and Bazin 1999; Liikanen et al. 2003; Sapulveda-Jauregui et al. 2015). However, in the seven coastal lakes studied, the $\mathrm{CH}_{4} / \mathrm{N}_{2}$ displayed irregular temporal changes. We believe that the seasonality was obscured by the forcing of gas ebullition by wind action which is known to enhance bubble releasement (Leventhal and Guntenspergen 2004; Bussmann 2005). On the other hand, the distribution of $\mathrm{CH}_{4}$ seems to be related to the distribution of macrophytes. This is corroborated by differences in CDMI between vegetated and non-vegetated sites (Fig. 3a). The highest CDMI (the more $\mathrm{CO}_{2}$ in relation to $\mathrm{CH}_{4}$ ) in Lake Kopań are explained by the fact that a large part of the lake bed (sites KOP1 and KOP4) is covered by macrophyte meadows, with Potamogeton as the predominant species. Aquatic (mainly emergent) plants are known to channel considerable amounts of $\mathrm{CH}_{4}$ from the sediments (Chanton 2005; Borges and Abril 2011). $\mathrm{CO}_{2}$ is removed in much lower rates (Olsson et al. 2015). Consequently, bioventilation leads to the increase in the CDMI in the sediment gas. Emergent plants (i.e. Phragmites, Typha etc.) transfer $\mathrm{CH}_{4}$ directly from the rhizosphere to the atmosphere, while submersed plants (i.e. Potamogeton) transmit $\mathrm{CH}_{4}$ to the water column, where it is oxidized (Laanbroek 2010). It was shown that in pore waters, in densely vegetated sites, the concentrations of dissolved $\mathrm{CH}_{4}$ were c.a. $50 \%$ lower than those in nonvegetated areas. The lower $\mathrm{CH}_{4}$ concentrations reduce the $\mathrm{CH}_{4}$ bubble formation and gas ebullition (Chanton 2005).

The transformation of the molecular composition of sediment gas in the water column of the coastal lakes studied conflicts with the findings of Del Sontro et al. (2010) and Katsman et al. (2013). These authors claimed that ascending gas bubbles rise quickly through the sediment and water columns, essentially by-passing the zones of anaerobic and aerobic microbial oxidation and, as a consequence, only a small fraction of gas fluxing into the boundary layer is lost.

Higher hydrocarbons (HHC) in sediment gas

$\mathrm{C}_{\mathrm{HC}}$ values in the gas samples from Polish coastal lakes are typical for microbial gases produced via methanogenesis (Bernard et al. 1978). Trace amounts of HHC were previously reported from microbial systems in lakes (Oremland and Des Marais 1983; Woszczyk et al. 2011), estuaries (Oremland 1981), and the ocean (Hinrichs et al. 2006). However, to the best of our knowledge, there are few data showing the production of HHC in lake sediments, and the mechanisms of gas formation remain unclear. Hinrichs et al. (2006) showed that $\mathrm{CH}_{4}$ and $\mathrm{HHC}$ can be co-produced during bacterial degradation of $\mathrm{OM}$ and established that the production of HHC is favored under low salinity (low sulfate) conditions. Therefore, the increase in salinity would result in an increase in $\mathrm{C}_{\mathrm{HC}}$, which conflicts with our observations (Fig. 4a). On the other hand, Whiticar and Faber (1986) found that changes in $\mathrm{C}_{\mathrm{HC}}$ values might be caused by selective removal of $\mathrm{CH}_{4}$ during anaerobic oxidation of hydrocarbons. $\mathrm{CH}_{4}$ shows lower resistance to this process than HHC (Whiticar and Faber 1986). In contrast, during aerobic oxidation HHC are preferentially decomposed compared with $\mathrm{CH}_{4}$ (Kinnaman et al. 2007). Thus the overall negative relation between the average $\mathrm{C}_{\mathrm{HC}}$ values and the lake water salinity in our lakes (Fig. 4a) may indicate that saltwater ingressions enhance anaerobic oxidation of $\mathrm{CH}_{4}$ in the sediments. This process is triggered by archaea in concert with SRB (Schouten et al. 2001). The latter were found to be one of the most predominant microbial communities in coastal lakes (Skórczewski and Mudryk 2005). The oxidation of $\mathrm{CH}_{4}$ becomes possible when the concentrations of dissolved sulfate are $>1 \mathrm{mmol} \mathrm{SO}_{4}{ }^{2-} \mathrm{L}^{-1}$ (Segers 1998). During the study period, the dissolved $\mathrm{SO}_{4}{ }^{2-}$ in the lakes varied between 0.17 and $3.9 \mathrm{mmol} \mathrm{L}^{-1}$ (unpubl. data), which made the $\mathrm{CH}_{4}$ oxidation thermodynamically possible.

In accord with previous reports (Utsumi et al. 1998; Whiticar 1999; Karim et al. 2011; Harley et al. 2015), the oxidation of $\mathrm{CH}_{4}$ is enhanced by higher water temperatures. This conclusion is supported by the decrease in $\mathrm{C}_{\mathrm{HC}}$ in warmer seasons (Fig. 4b) and a concomitant increase in CDMI (Fig. 3b). However, the 
increase in CDMI is not accompanied by a decline in $\delta^{13} \mathrm{C}_{\mathrm{CO} 2}$, which would be expected during $\mathrm{CH}_{4}$ oxidation (Jędrysek 1999). It appears, therefore, that anaerobic oxidation plays only a minor role in the $\mathrm{CH}_{4}$ cycling in coastal lakes albeit its effect on the $\mathrm{C}_{\mathrm{HC}}$ may be strong. The concentrations of $\mathrm{CH}_{4}$ are 4-5 orders of magnitude higher that the HHCs and even a small decline in $\mathrm{CH}_{4}$ due to oxidation drives the $\mathrm{C}_{\mathrm{HC}}$ towards higher values.

\section{Mechanisms of methanogenesis in coastal lakes}

The two primary methanogenic pathways suspected in the lakes are acetoclastic methanogenesis (AM) and hydrogenotrophic methanogenesis (HM). Whiticar and Faber (1986) and others argued that in marine sediments HM predominates. This is due to the utilization of potential methanogenic precursor organic substrates by SRB in the sulfate reduction zone, before they reached the diagenetic depth for methanogenesis. To complicate the issue, aerobic and anaerobic $\mathrm{CH}_{4}$ oxidation consume some of the $\mathrm{CH}_{4}$, while the remainder can flux out of the lakes into the troposphere.

The $\mathrm{CH}_{4}$ production and consumption pathway can be recognized on the basis of the apparent $\mathrm{C}$ isotope fractionation factor between $\mathrm{CO}_{2}$ and $\mathrm{CH}_{4}$ (Whiticar 1999):

$\alpha_{\mathrm{C}}=\left(\delta^{13} \mathrm{C}_{\mathrm{CO} 2}+10^{3}\right) /\left(\delta^{13} \mathrm{C}_{\mathrm{CH} 4}+10^{3}\right)$

as well as by using the $\delta^{2} \mathrm{H}_{\mathrm{CH} 4}$ signatures. The $\delta^{13} \mathrm{C}_{\mathrm{CO} 2}$ versus $\delta^{13} \mathrm{C}_{\mathrm{CH} 4}$ relationships assume so-called coexisting pairs, i.e., that $\mathrm{CO}_{2}$ and $\mathrm{CH}_{4}$ are mechanistically linked. When this condition is fulfilled, $\alpha_{C}>1.065$ is characteristic for HR, while $\alpha_{C}<1.055$ indicates the predominance of AM (Conrad 2005; Hershey et al. 2014). On the other hand, in the $\mathrm{C} / \mathrm{H}$ isotope systematics of $\mathrm{CH}_{4}$, the demarcation lines between $\mathrm{AM}$ and $\mathrm{HM}$ are made at $\delta^{13} \mathrm{C}_{\mathrm{CH} 4} \sim-60 \%$ and $\delta^{2} \mathrm{H}_{\mathrm{CH} 4} \sim-250 \%$ (Whiticar 1999). The lower values denote $\mathrm{AM}$, while $\mathrm{HM}$ has $\delta^{13} \mathrm{C}_{\mathrm{CH} 4}>-60 \%$ and $\delta^{2} \mathrm{H}_{\mathrm{CH} 4}>-250 \%$. For $\mathrm{CH}_{4}$ oxidation, in turn, the $\mathrm{C}$ isotope fractionation factor is usually $1.005<$ $\alpha_{\mathrm{C}}<1.031$ (Whiticar and Faber 1986).

In the previous section we showed that the molecular composition of gas in rising bubbles can change significantly in a lake water column. It seems, however, that the gases preserve their original stable $\mathrm{C}$ isotope signatures because the isotope effects associated with dissolving $\mathrm{CH}_{4}$ and $\mathrm{CO}_{2}$ in water are small (0.3-0.6 and 1\%, respectively) (Bergamaschi 1997; Sansone et al. 1999; McGinnis et al. 2011).

Most of the gas samples from coastal lakes reveal the stable $\mathrm{C}$ and $\mathrm{H}$ isotopic signatures indicative of $\mathrm{AM}$ (Figs. 5, 8). However, several samples show $\alpha_{\mathrm{C}}>1.055$, arguing for minor contribution from HM; and a few samples display $\alpha_{\mathrm{C}}<1.031$, characteristic for $\mathrm{CH}_{4}$ oxidation. In the case of a few samples from Lake Bukowo, Lake Wicko and Lake Kopań, both $\delta^{13} \mathrm{C}_{\mathrm{CO} 2}-$ $\delta^{13} \mathrm{C}_{\mathrm{CH} 4}$ and $\delta^{13} \mathrm{C}_{\mathrm{CH} 4}-\delta^{2} \mathrm{H}_{\mathrm{CH} 4}$ signatures consistently indicate some $\mathrm{HM}$ contribution. The dominance of $\mathrm{AM}$ in the lakes is consistent with low sulphate, freshwater conditions. The shift towards HM for some samples may indicate the exhaustion of the labile AM substrates and a shift in methanogenic pathway. Hornibrook et al. (2000) claimed that recalcitrance of sedimentary organic matter (SOM) acts as one of key factors controlling the mechanism of $\mathrm{CH}_{4}$ production. The more labile the organic matter delivered to the methanogenic zone, the higher the preference for AM.

The $\delta^{13} \mathrm{C}_{\mathrm{CO} 2}$ and $\delta^{13} \mathrm{C}_{\mathrm{CH} 4}$ show weak seasonality, with a tendency to enhanced HM during colder periods and enhanced AM during warmer periods (Fig. 5). This agrees with previous reports (Hornibrook et al. 2000; Avery et al. 2003; Chanton et al. 2005) and may be related to formation and abundance of precursor substrates for AM. However, the temporal patterns of $\delta^{13} \mathrm{C}_{\mathrm{CO} 2}$ and $\delta^{13} \mathrm{C}_{\mathrm{CH} 4}$ are different in each lake; consequently, there is no compelling evidence of a significant climatic (temperature) control on methanogenesis.

Based solely on $\delta^{13} \mathrm{C}_{\mathrm{CO} 2}$ vs $\delta^{13} \mathrm{C}_{\mathrm{CH} 4}$, the methanogenic pathway in the lakes would appear to be influenced by water depth (Fig. 5). The $\delta^{13} \mathrm{C}_{\mathrm{CO} 2}$, and to a lesser extent the $\delta^{13} \mathrm{C}_{\mathrm{CH} 4}$, become ${ }^{12} \mathrm{C}$-enriched with increasing water depth. There is also a shift in $\alpha_{C}$ to lower values with depth. This would suggest enhanced AM over HM at depth. This conclusion contrasts with observations by Jędrysek (1999) and Alstad and Whiticar (2011) who argued that HM should dominate in deeper waters. The transition from AM to $\mathrm{HM}$ with depth is hypothesized to be due to a depletion by utilization of labile AM precursor substrates in the deeper waters, and by higher availability of dissolved $\mathrm{CO}_{2}$ in deeper waters. We believe that such reasoning is not valid for the seven lakes studied, because in our data there is neither clear evidence for substantial differences in dissolved $\mathrm{CO}_{2}$ within lakes nor differences in the decomposition of SOM throughout the lakes (the $\mathrm{TOC} / \mathrm{N}$ and $\delta^{13} \mathrm{C}_{\mathrm{TOC}}$ show only minor variability 
within each lake) (Table 2). In addition, because the $\delta^{2} \mathrm{H}_{\mathrm{CH} 4}$ values are not related to water depth, the overall isotope evidence does not support a shift from HM to AM with depth. Therefore, we suggest that the stable isotope composition of microbial gases is altered by secondary processes.

\section{Methane oxidation}

The observed shifts in $\alpha_{\mathrm{C}}$ in the lakes are determined more by changes in $\delta^{13} \mathrm{C}_{\mathrm{CO} 2}$ than in $\delta^{13} \mathrm{C}_{\mathrm{CH} 4}$, and with increasing water depth the $\delta^{13} \mathrm{C}_{\mathrm{CO} 2}$ values decline to $<-35 \%$ (the minimum $\delta^{13} \mathrm{C}_{\mathrm{CO} 2}$ is $-51 \%$ ) (Fig. 5). Such low $\delta^{13} \mathrm{C}_{\mathrm{CO} 2}$ values can only be explained by methanotrophy, i.e., the oxidation of ${ }^{13} \mathrm{C}$-depleted microbial $\mathrm{CH}_{4}$. Other remineralization reactions, such as organic matter respiration, could not result in the observed highly negative $\delta^{13} \mathrm{C}_{\mathrm{CO} 2}$ because these processes produce $\mathrm{CO}_{2}$ in which $\delta^{13} \mathrm{C}$ signatures are close to $\delta^{13} \mathrm{C}_{\mathrm{TOC}}$ (i.e. between -24 and $-29 \%$; Table 2). The oxidation of $\mathrm{CH}_{4}$ occurred during summer and autumn (Fig. 5). We hypothesize that enhanced oxidation in deeper water is related to the intense windinduced lake water mixing which is known to drive methanogenesis to greater depths within the sediments (Blair 1998). The oxidation of $\mathrm{CH}_{4}$ can be performed within the pore waters and in the water column. In the former case the oxidation is under reducing conditions and enhanced $\mathrm{SO}_{4}$ concentration. Earlier in this paper we postulated that the oxidation of $\mathrm{CH}_{4}$ at the expense of $\mathrm{SO}_{4}$ could be responsible for the lowered $\mathrm{C}_{\mathrm{HC}}$ values in the gas collected during saltwater inflows to coastal lakes. However, the lack of correlation between $\delta^{13} \mathrm{C}_{\mathrm{CH} 4}$ and lake water salinity shows that this process has a negligible isotope effect.

Methanotrophic bacteria existing in lake water column consume methane during its diffusion and/or bubble transport via the oxidized water (Schubert et al. 2010). However, in the case of ascending bubbles the oxidation is minor due to the very short contact of bubble $\mathrm{CH}_{4}$ with $\mathrm{O}_{2}$ in the water column (Liikanen et al. 2003; Chanton 2005). Interestingly ${ }^{12} \mathrm{C}$-enriched $\delta^{13} \mathrm{C}_{\mathrm{CO} 2}$ values correspond to low concentrations of $\mathrm{CO}_{2}$ (Fig. 6) which seems inconsistent with methanotrophy because the enhanced oxidation of $\mathrm{CH}_{4}$ and $\mathrm{OM}$ is expected to deliver more $\mathrm{CO}_{2}$ than $\mathrm{CH}_{4}$ (Hornibrook et al. 2000) and thus leads to higher CDMI. Interpreting the low $\mathrm{CO}_{2}$ and ${ }^{12} \mathrm{C}$-enriched $\delta^{13} \mathrm{C}_{\mathrm{CO} 2}$ values in terms of methanotrophy would imply that all the excess $\mathrm{CO}_{2}$ was removed from the gas phase. In light of the model proposed by McGinnis et al. (2011), the plausible explanation for the $\mathrm{CO}_{2}$ removal is rapid dissolution of $\mathrm{CO}_{2}$ from ascending bubbles in the water column.

The effect of $\mathrm{CH}_{4}$ oxidation fades out in gas samples from the shallow water sections of the lakes where less negative or even highly positive $\delta^{13} \mathrm{C}_{\mathrm{CO} 2}$ values of 0 to $+6 \%$ were obtained. These signatures are attributed to methanogenesis. Methanogenic origin of shallow water $\mathrm{CO}_{2}$ is corroborated by the mass balance calculation relating stable $\mathrm{C}$ isotope composition of $\mathrm{CO}_{2}$ and $\mathrm{CH}_{4}$ to the $\delta^{13} \mathrm{C}_{\mathrm{OM}}$ of the precursor organic material. From the equation proposed by Corbett et al. (2013):

$\delta^{13} \mathrm{C}_{\mathrm{OM}}=0.5 \cdot \delta^{13} \mathrm{C}_{\mathrm{CO} 2}+0.5 \cdot \delta^{13} \mathrm{C}_{\mathrm{CH} 4}$

we derived $\delta^{13} \mathrm{C}_{\mathrm{OM}}$ values ranging from -26.2 to $-29.9 \%$, which are close to the measured $\delta^{13} \mathrm{C}_{\mathrm{TOC}}$ of -24.4 to $-29.1 \%$ (Table 2) thus indicating that $\delta^{13} \mathrm{C}_{\mathrm{CO} 2}$ fits well the expected stable $\mathrm{C}$ isotope composition of $\mathrm{CO}_{2}$ produced from the organic matter in the lakes' sediments.

Shallow water sites are less affected by oxidation, presumably due to location in wind-protected embayments and/or dissipation of water energy by macrophytes.

The effect of ebullition on $\delta^{13} \mathrm{C}_{\mathrm{CH} 4}$ and $\delta^{13} \mathrm{C}_{\mathrm{CO} 2}$

The stable isotope composition of the gas can be influenced by the rate of ebullition. Ebullition itself causes rather low $\mathrm{C}$ fractionation, with a tendency for the dissolved forms of $\mathrm{CH}_{4}$ and $\mathrm{CO}_{2}\left(\mathrm{CH}_{4 \text { diss }}\right.$ and $\mathrm{CO}_{2 \text { diss }}$, respectively) to be slightly enriched in ${ }^{12} \mathrm{C}$ (Hornibrook et al. 2000). However, when methanogenically derived $\mathrm{CH}_{4}$ and $\mathrm{CO}_{2}$ are constantly removed from the sediments by intense ebullition $\delta^{13} \mathrm{C}$ in remaining gases becomes progressively heavier in accordance with the Rayleigh relationship (Whiticar 1999). Moreover, since the solubility of $\mathrm{CO}_{2}$ and $\alpha_{\mathrm{C}}$ for this reaction are higher than for $\mathrm{CH}_{4}$, the increase in $\delta^{13} \mathrm{C}_{\mathrm{CO} 2}$ is expected to be higher than in $\delta^{13} \mathrm{C}_{\mathrm{CH} 4}$. We believe that this process contributes to the variability in the stable $\mathrm{C}$ isotope composition of gases throughout the coastal lakes, because there are differences in the rate of ebullition as shown by the $\mathrm{CH}_{4} / \mathrm{N}_{2}$ ratio. The shallower parts of the lakes display more intense ebullition as well as higher $\delta^{13} \mathrm{C}_{\mathrm{CH} 4}$ and $\delta^{13} \mathrm{C}_{\mathrm{CO} 2}$ compared with the deeper parts. On the other hand, the lower rate of ebullition in deeper parts of the lakes may be 
responsible for the prolonged contact of $\mathrm{CH}_{4}$ with oxygenated water and thus lead to more intense oxidation of $\mathrm{CH}_{4}$.

The effect of bioventilation on $\delta^{13} \mathrm{C}_{\mathrm{CH} 4}$ and $\delta^{13} \mathrm{C}_{\mathrm{CO} 2}$

It was shown earlier that the composition of gas may be modified due to ventilation by macrophytes (Fig. 3a). It has been recognized that the removal of $\mathrm{CH}_{4}$ by macrophytes is an isotope fractionating process discriminating against ${ }^{13} \mathrm{C}$ and leaving residual $\mathrm{CH}_{4}$ with higher $\delta^{13} \mathrm{C}_{\mathrm{CH} 4}$ signatures (Chanton 2005). Whether or not there is an analogous effect for methanogenically derived $\mathrm{CO}_{2}$ in the rhizosphere is uncertain, as is the magnitude of the isotope fractionation. On the other hand, the macrophytes are known to shift $\delta^{13} \mathrm{C}_{\mathrm{CH} 4}$ towards higher values by the enhanced deposition of metabolizable $\mathrm{OM}$ in the proximity of vegetation (Blair 1998). The influence of macrophytes on the stable $\mathrm{C}$ isotope composition of $\mathrm{CO}_{2}$ and $\mathrm{CH}_{4}$ can be seen in Fig.7, where there is a noticeable difference between vegetated and non-vegetated sites. The former have $3.6 \%$ higher $\delta^{13} \mathrm{C}_{\mathrm{CH} 4}$ and $10.5 \%$ higher $\delta^{13} \mathrm{C}_{\mathrm{CO} 2}$ values than the latter.

\section{Conclusions}

This paper provides a comprehensive study of microbial gas production in the ecosystem of Polish coastal lakes located on the non-tidal Baltic coast. The molecular and stable isotope compositions of the gases show differences between the seven lakes studied and within each lake, due to variations in the biogeochemical processes. These are modulated by the overall complexity of coastal lakes, including the high biological activity, spatial and temporal salinity changes, the very high water column turbulence and vertical mixing of sediments. The increasing lake depth results in a depletion in $\mathrm{CH}_{4}$ and $\mathrm{CO}_{2}$ in the bubbles in favor of $\mathrm{N}_{2}$ and $\mathrm{O}_{2}$. A large part of microbially produced $\mathrm{CH}_{4}$ and $\mathrm{CO}_{2}$ in the sediments is removed in the lake water column by the dissolution of rising bubbles and gas exchange with the ambient water. The aquatic macrophytes also affect the compositions of microbial gas. From our data it emerged that in vegetated parts of the lakes, the $\mathrm{CH}_{4}$ is depleted in favor of $\mathrm{CO}_{2}$ and that the residual $\mathrm{CH}_{4}$ and $\mathrm{CO}_{2}$ are enriched in ${ }^{13} \mathrm{C}$. The removal of $\mathrm{CH}_{4}$ from the bubbles via dissolution and bioventilation acts as a primary source of the dissolved $\mathrm{CH}_{4}$ pool in the water column of coastal lakes. Despite the fact that the coastal lakes display highly oxidizing conditions in the water column and that the bottom sediments are prone to intense mixing by wind waves, the $\mathrm{CH}_{4}$ reveals rather low oxidation, except for the $\mathrm{CH}_{4}$ produced in the deepest parts of the lakes. The oxidation of $\mathrm{CH}_{4}$ in deeper waters seems to be related to lower rates of ebullition and thus longer exposure to oxygenated waters, as well as to the penetration of $\mathrm{O}_{2}$ to the pore waters during vertical mixing of sediments.

In the seven lakes studied there is no clear relationship between salinity and the stable $\mathrm{C}$ and $\mathrm{H}$ isotope composition of sediment gas. It seems, however, that salinity may influence the molecular composition of hydrocarbons via preferential oxidation of $\mathrm{CH}_{4}$.

Given the remarkable dissolution of gas bubbles in the water column, the effect of salinity on $\mathrm{CH}_{4}$ oxidation and the $\mathrm{C}$ isotope effects accompanying bioventilation both require further investigations to decipher the mechanisms driving these processes.

On the other hand, the data obtained in the current study will assist in the assessment of the emissions of $\mathrm{CH}_{4}$ and $\mathrm{CO}_{2}$ from coastal lakes. Our observations have provided the basis for establishing the representative monitoring sites in which reliable estimations of ebulitive and diffusive emission of gases from the lakes can be performed.

Acknowledgements The study was funded by the National Science Center (Poland) (Grant No. 2012/05/B/ST10/00295). The assistance of Tomasz Kurczaba, Paweł Młodkowski, and Paweł Kaczmarek during the field campaigns is greatly appreciated. The molecular and stable isotope compositions of sediment gas were determined by Tomasz Kowalski and Adam Kowalski (AGH UST Kraków, Poland).

Open Access This article is distributed under the terms of the Creative Commons Attribution 4.0 International License (http:// creativecommons.org/licenses/by/4.0/), which permits unrestricted use, distribution, and reproduction in any medium, provided you give appropriate credit to the original author(s) and the source, provide a link to the Creative Commons license, and indicate if changes were made.

\section{Appendix}

See Tables 3 and 4. 


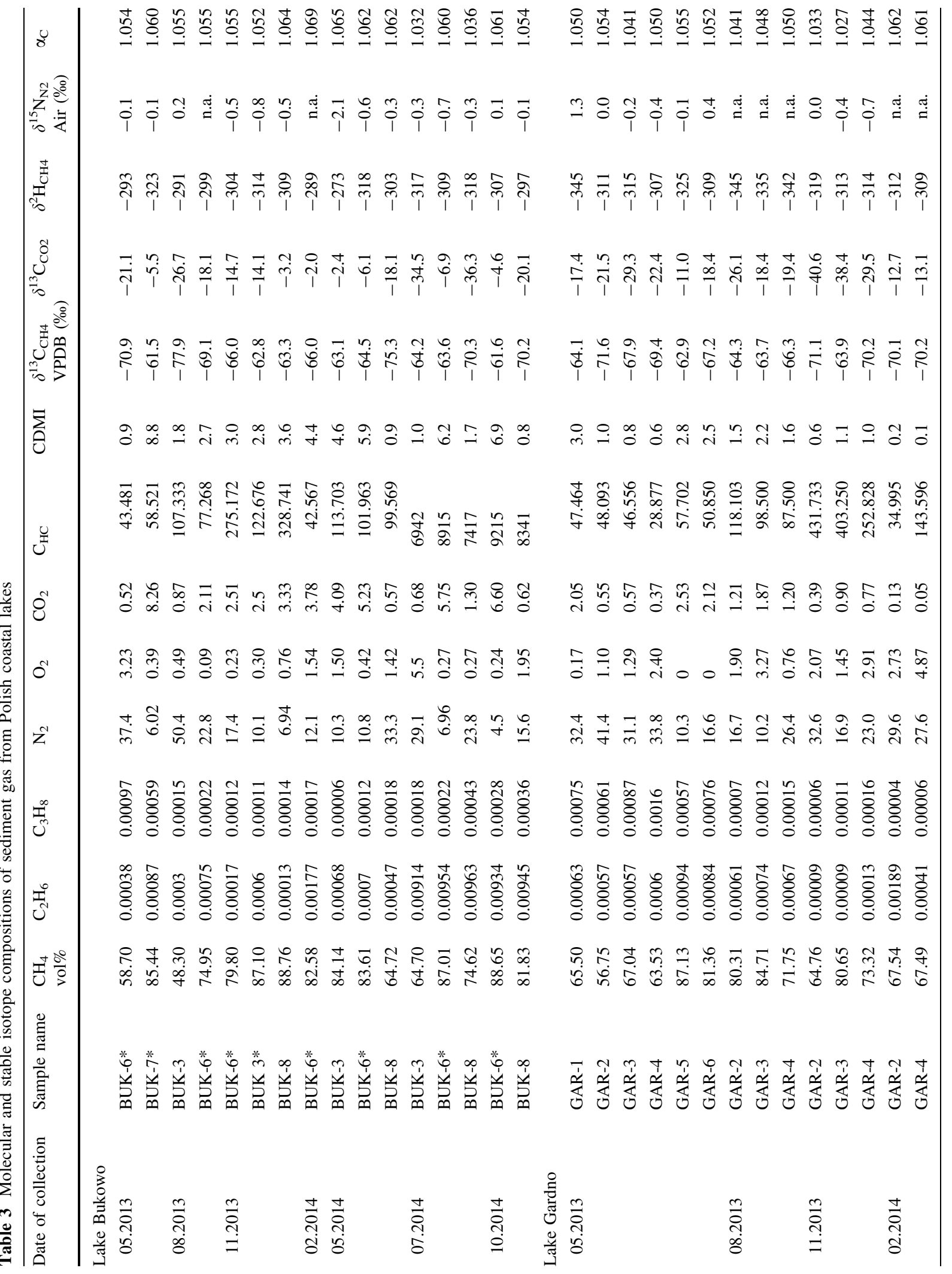




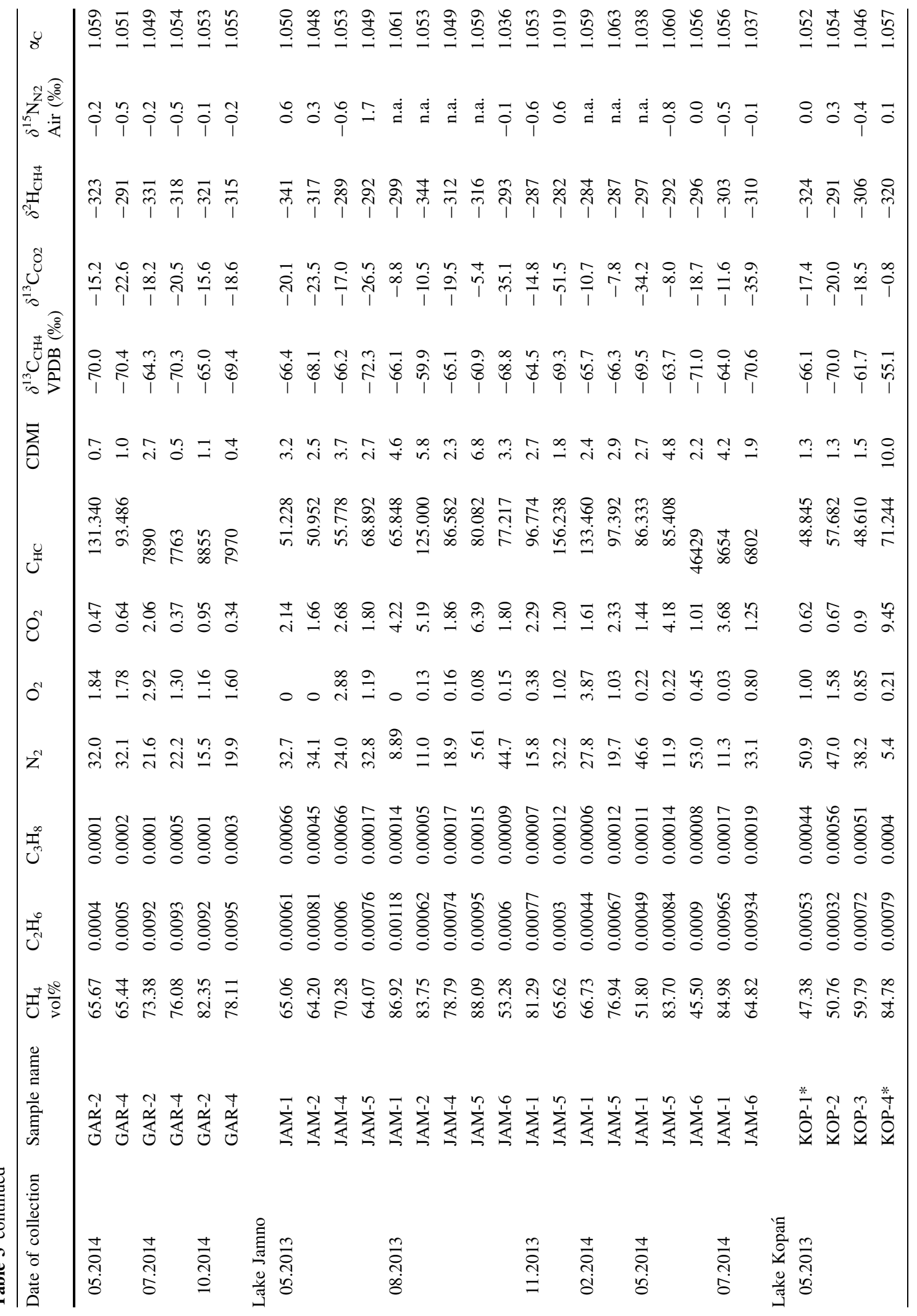




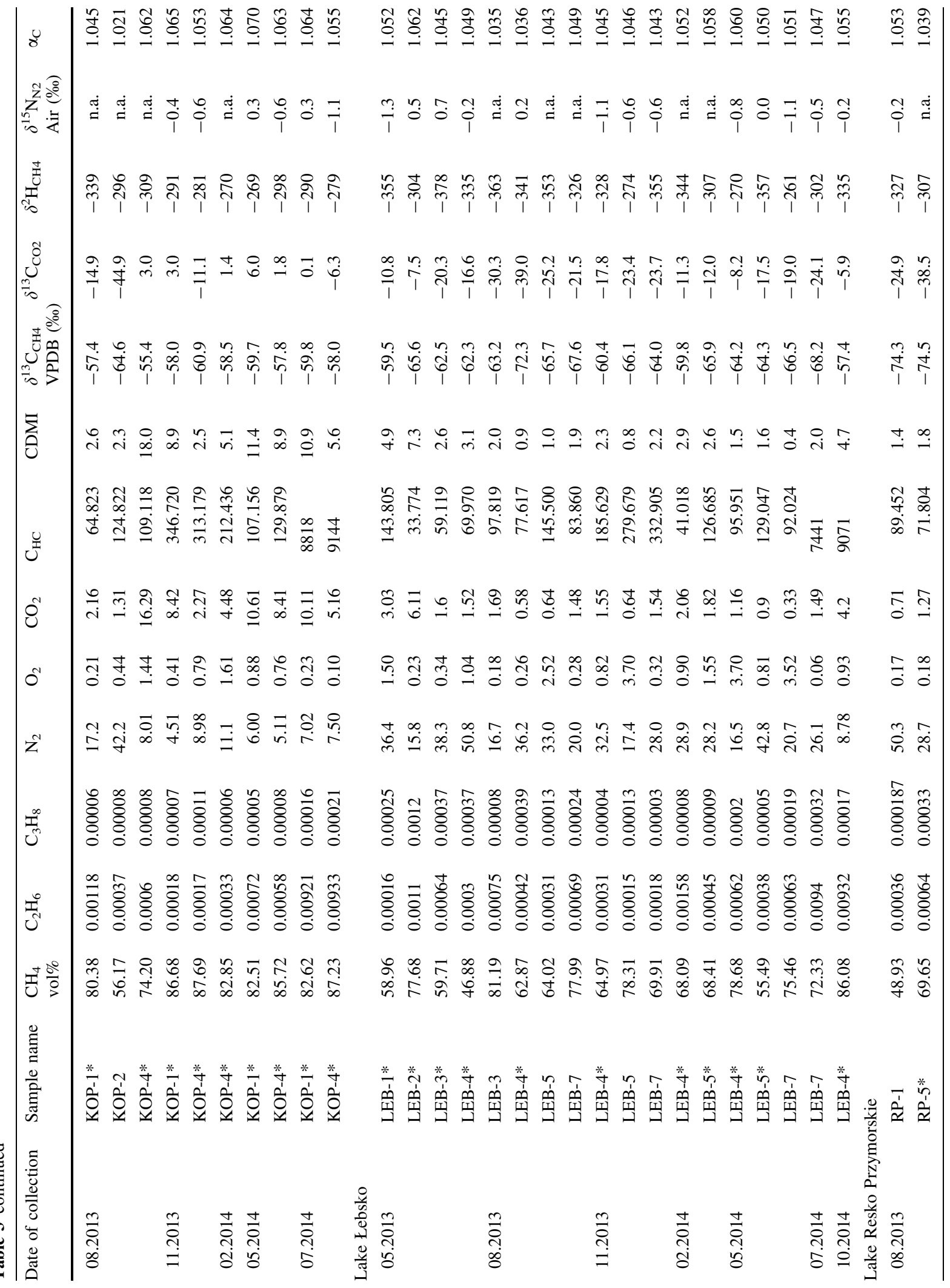




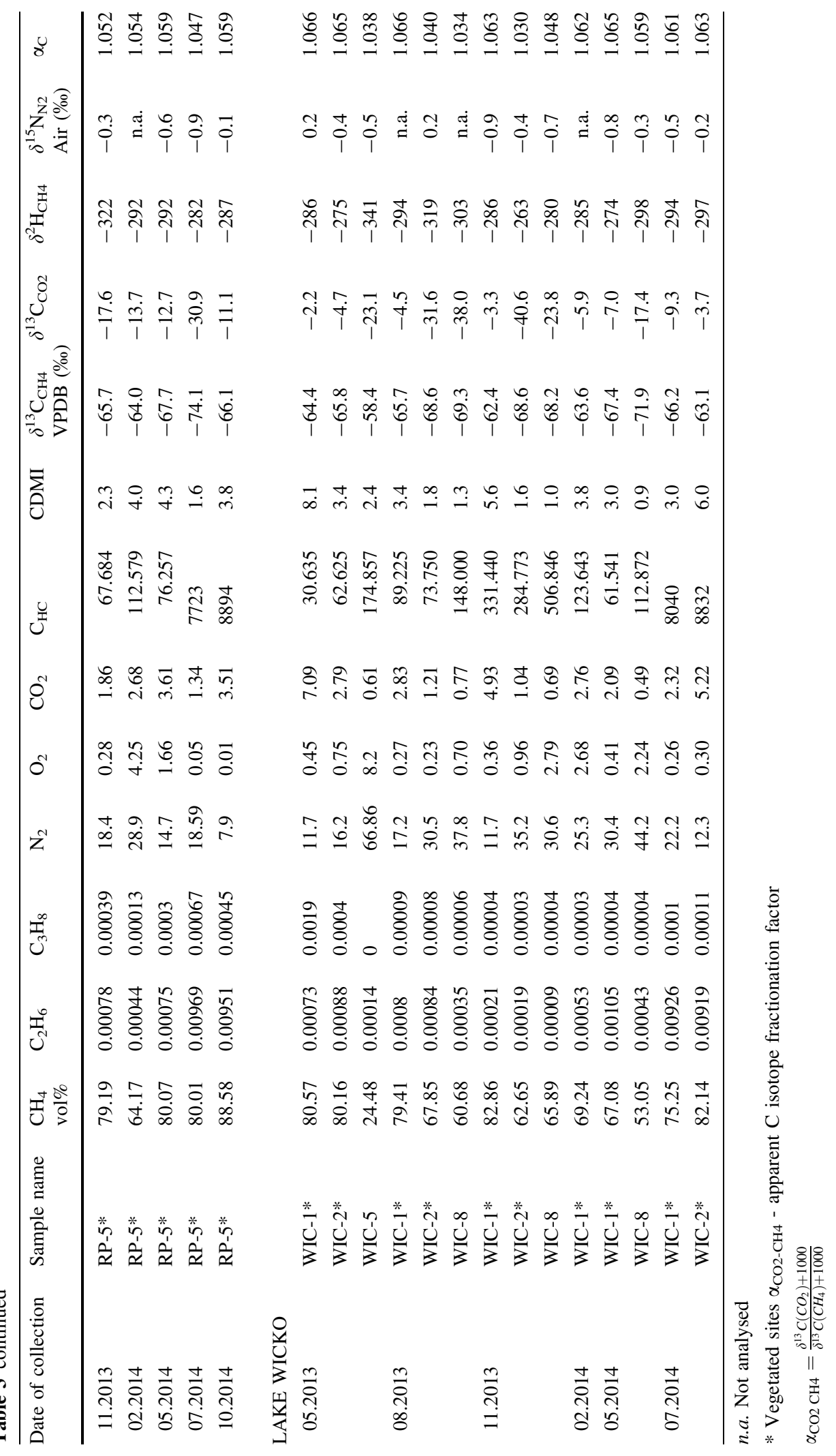




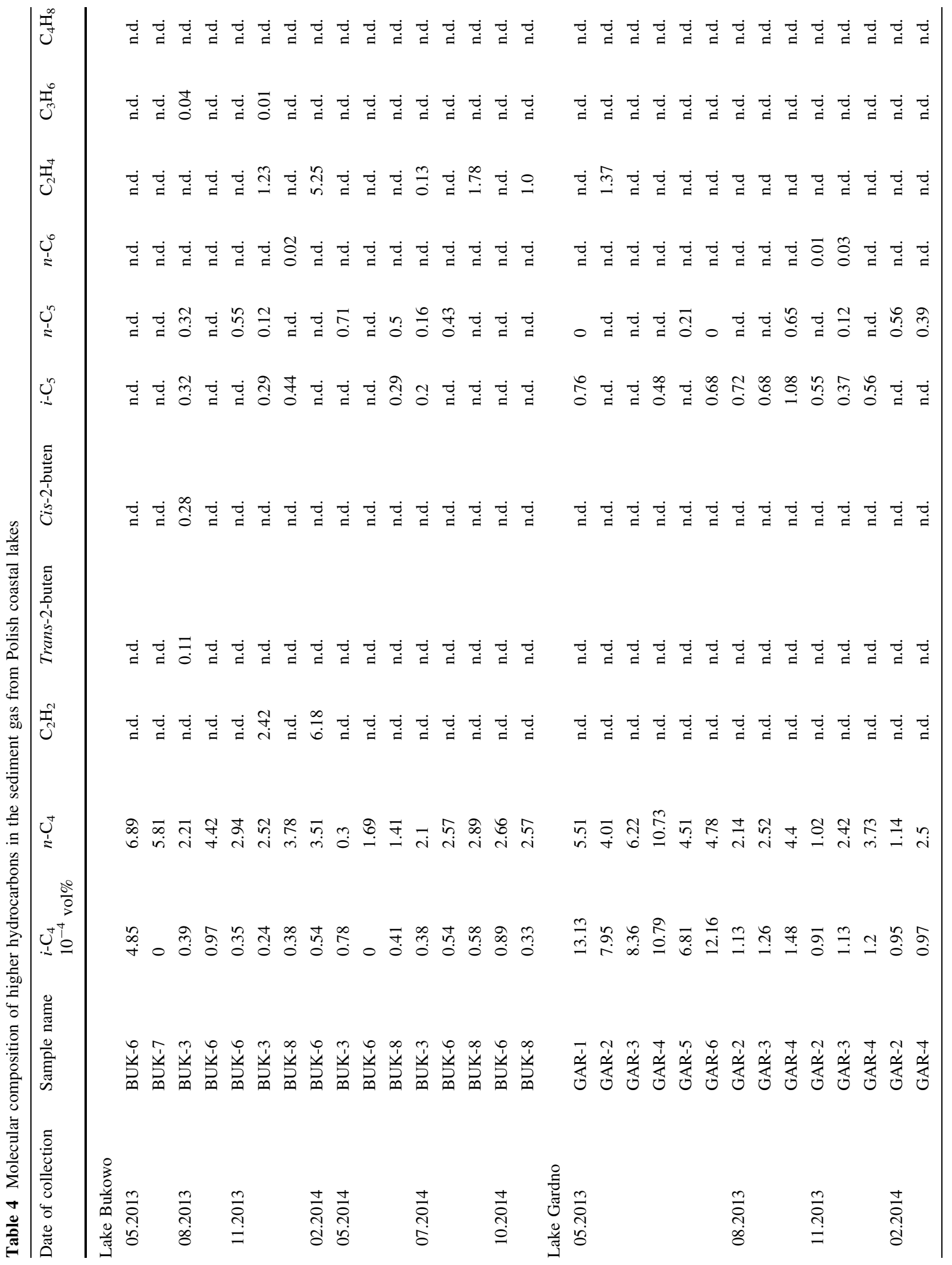




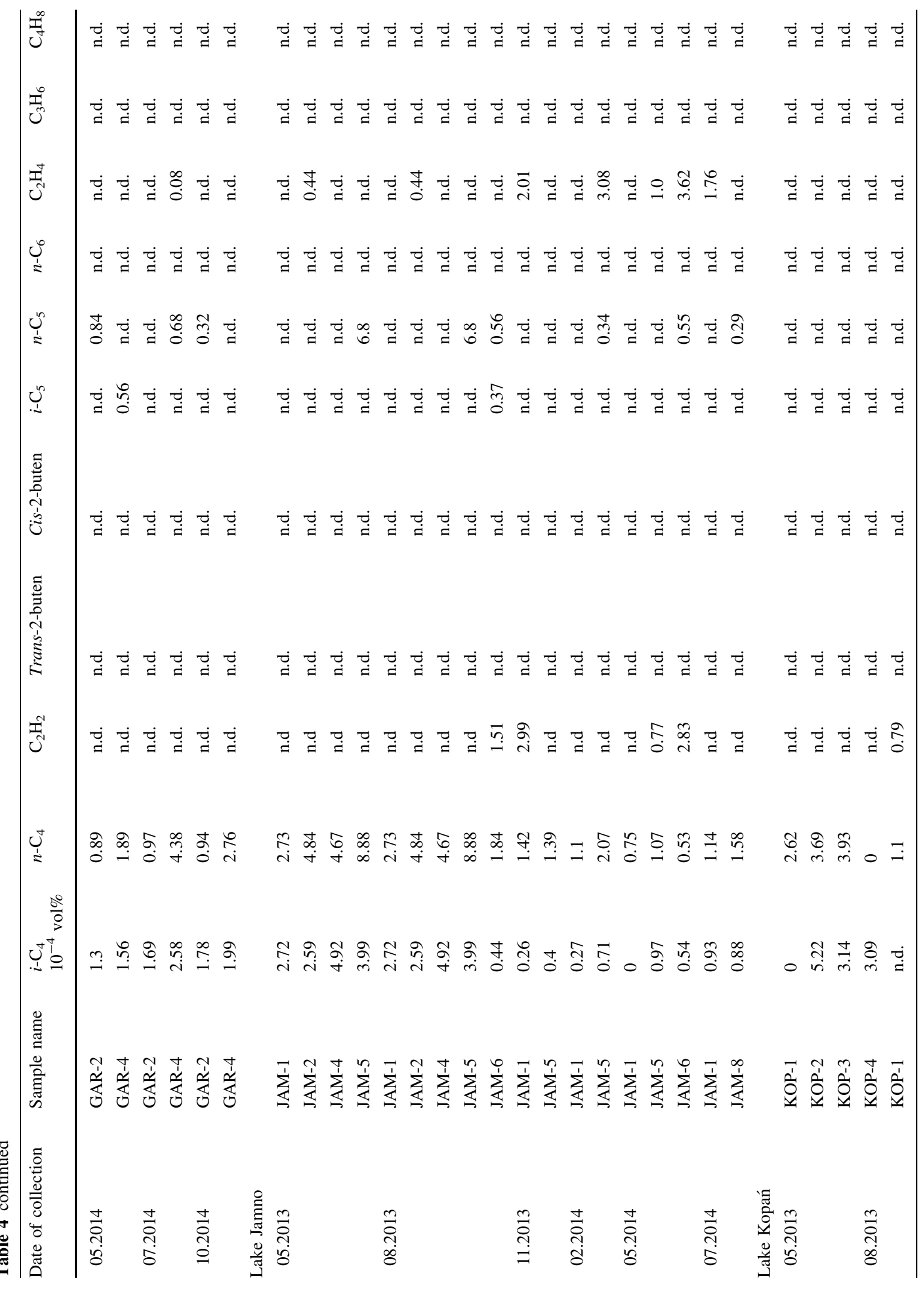




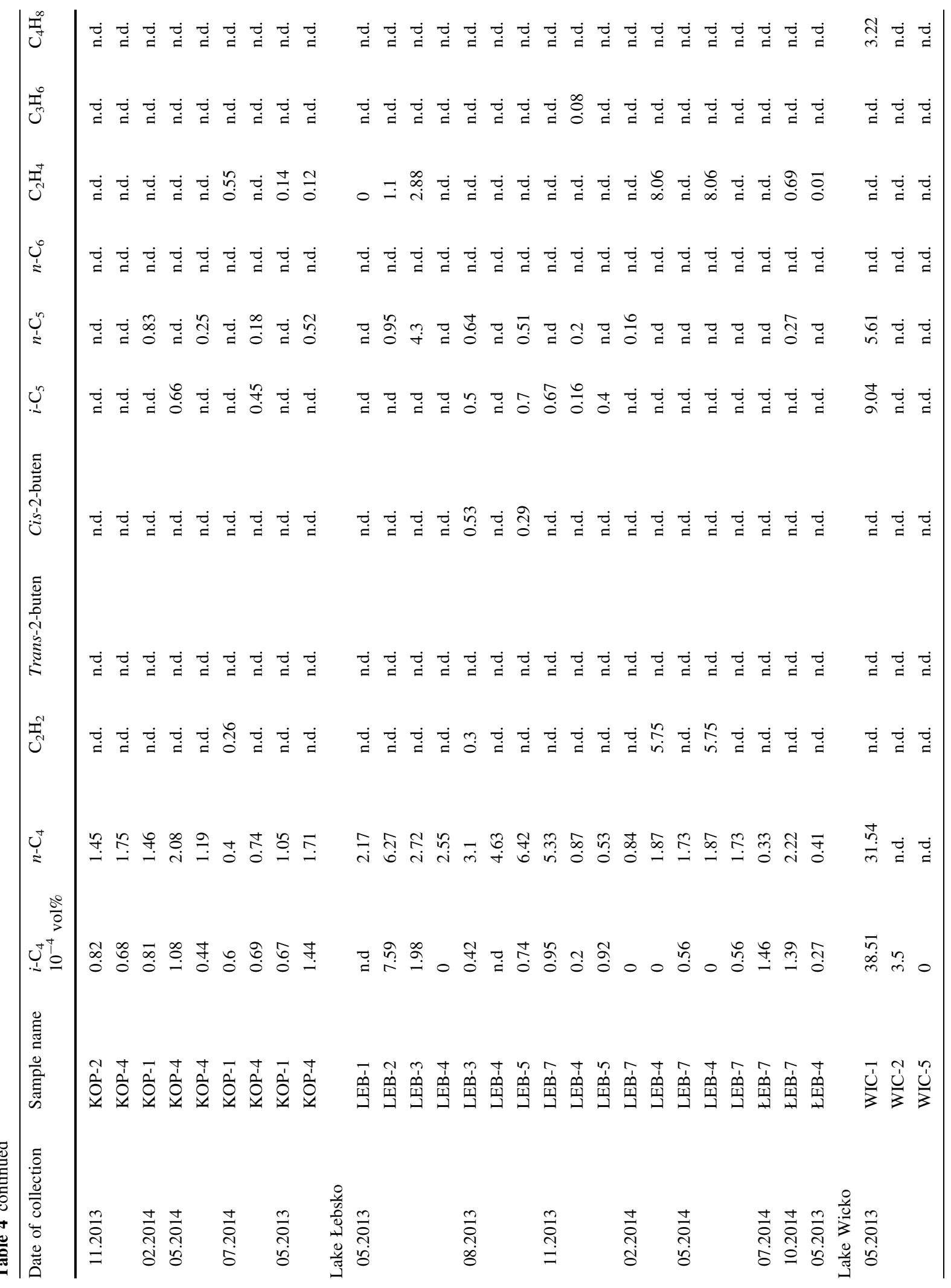




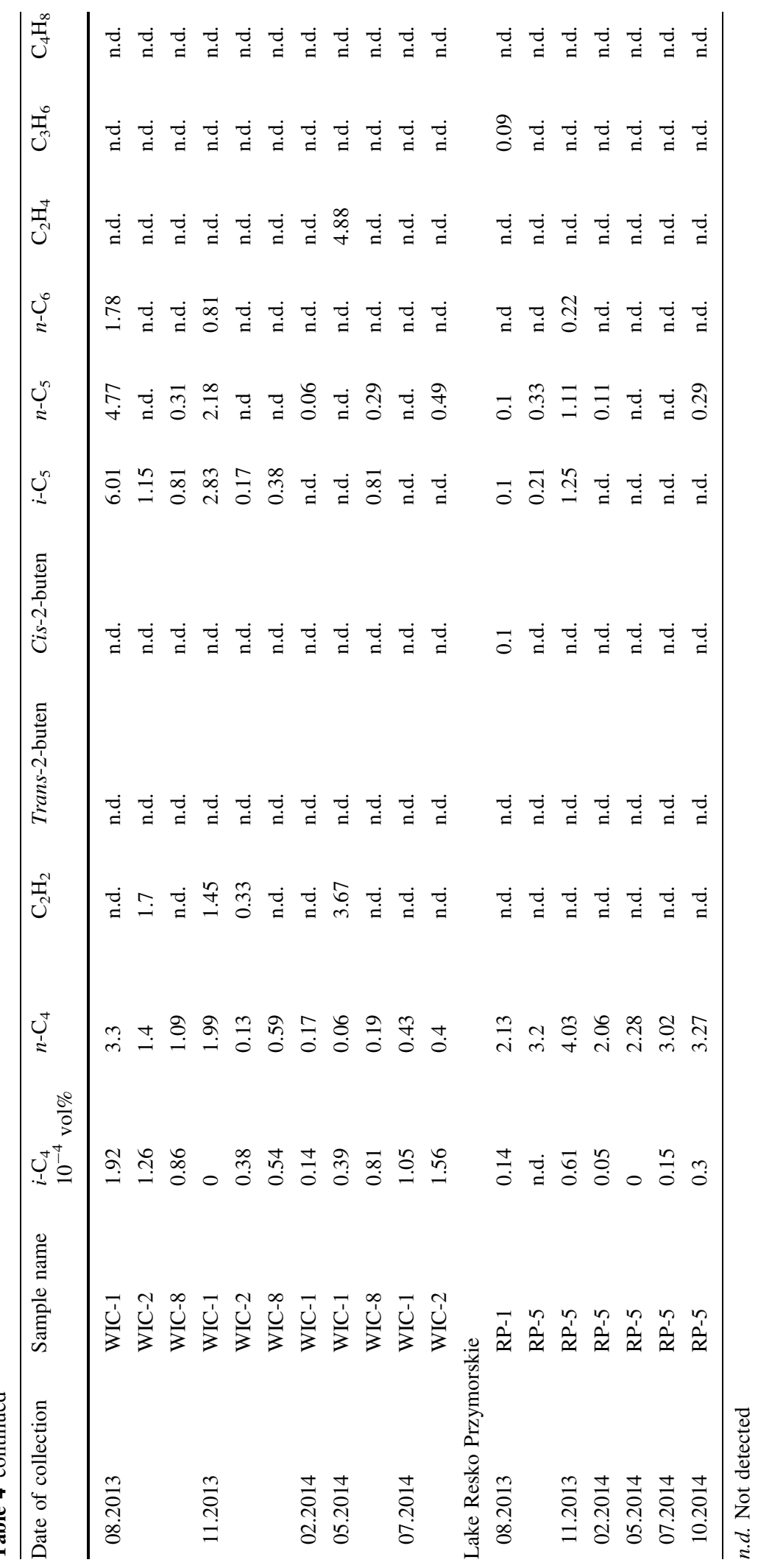




\section{References}

Alstad KP, Whiticar MJ (2011) Carbon and hydrogen isotope ratio characterization of methane dynamics for fluxnet peatland ecosystems. Org Geochem 42(5):548-558

Avery GB Jr, Shannon RD, White JR, Martens CS, Alperin MJ (2003) Controls on methane production in a tidal freshwater estuary and a peatland: methane production via acetate fermentation and $\mathrm{CO}_{2}$ reduction. Biogeochemistry 62:19-37

Bange HW (2006) Nitrous oxide and methane in European coastal waters. Estuar Coast Shelf Sci 70:361-374

Bastviken D, Tranvik LJ, Downing JA, Crill PM, Enrich-Prast A (2011) Freshwater methane emissions offset the continental carbon sink. Science 331:50

Bauer JE, Cai W-J, Raymond PA, Bianchi TS, Hopkinson CS, Regnier PAG (2013) The changing carbon cycle of the coastal ocean. Nature 504:61-70

Bergamaschi P (1997) Seasonal variations of stable hydrogen and carbon isotope ratios in methane from a Chinese rice paddy. J Geophys Res 102(25):383-393

Bernard BB, Brooks JM, Sackett WM (1978) Light hydrocarbons in recent Texas continental shelf and slope sediments. J Geophys Res 83:4053-4061

Blair N (1998) The $\delta^{13} \mathrm{C}$ of biogenic methane in marine sediments: the influence of $\mathrm{C}_{\text {org }}$ deposition rate. Chem Geol 152:139-150

Borges AV, Abril G (2011) Carbon dioxide and methane dynamics in estuaries. In: Wolanski E, McLusky D (eds) Treatise on estuarine and coastal science, vol 5., BiogeochemistryAcademic Press, Waltham, pp 119-161

Borges AV, Schiettecatte LS, Abril G, Delille B, Gazeau F (2006) Carbon dioxide in European coastal waters. Estuar Coast Shelf Sci 70:375-387

Boudreau BP (2012) The physics of bubbles in surficial, soft, cohesive sediments. Mar Pet Geol 38:1-18

Bussmann I (2005) Methane release through resuspension of littoral sediment. Biogeochemistry 74:283-302

Chanton JP (2005) The effect of gas transport on the isotope signature of methane in wetlands. Org Geochem 36:753-768

Chanton JP, Martens CS, Kelly CA (1989) Gas transport from methane-saturated, tidal freshwater and wetland sediments. Limnol Oceanogr 34(5):807-819

Chanton J, Chaser L, Glasser P, Siegel D (2005) Carbon and hydrogen isotopic effects in microbial methane from terrestrial environments. In: Flanagan LB et al (eds) Stable isotopes and biosphere-atmosphere interactions. Elsevier Inc., Amsterdam, pp 85-105

Chiba D, Baschek B (2010) Effect of langmuir cells on bubble dissolution and air-sea gas exchange. J Geophys Res 115:C10046

Cieśliński R, Drwal J (2005) Quasi-estuary processes and consequences for human activity, south Baltic. Estuar Coast Shelf Sci 62:477-485

Cole JJ, Praire YT, Caraco NF, McDowell WH, Travnik IJ, Striegl RG, Duarte CM, Kortelainen P, Downing JA, Middleburg JJ, Malack J (2007) Plumbing the global carbon cycle: integrating inland waters and the terrestrial carbon budget. Ecosystems 10:171-184
Conrad R (2005) Quantification of methanogenic pathways using stable carbon isotopic signatures: a review and a proposal. Org Geochem 36:739-752

Coplen TB (2011) Guidelines and recommended terms for expression of stable-isotope-ratio and gas-ratio measurement results. Rapid Commun Mass Spectrom 25: 2538-2560

Corbett JE, Tfaily MM, Burdige DJ, Cooper WT, Glaser PH, Chanton JP (2013) Partitioning pathways of $\mathrm{CO}_{2}$ production in peatlands with stable carbon isotopes. Biogeochemistry $114: 327-340$

Day JW, Christian RR, Boesch DM, Yáñez-Arancibia A, Morris J, Twilley RR, Naylor L, Schaffner L, Stevenson C (2008) Consequences of climate change on the ecogeomorphology of coastal wetlands. Estuar Coast 31:477-491

Del Sontro T, McGinnis DF, Sobek S, Ostrovsky I, Wehrli B (2010) Extreme methane emissions from a Swiss hydropower reservoir: contribution from bubbling sediments. Environ Sci Technol 44:2419-2425

Douglas RW, Rippey B (2000) The random redistribution of sediment by wind in a lake. Limnol Oceanogr 45(3):686-694

Engle D, Melack JM (2000) Methane emissions from an Amazon floodplain lake: enhanced release during episodic mixing and during falling water. Biogeochemistry 51:71-90

Farmer DM, McNeil CL, Johnson BD (1993) Evidence for the importance of bubbles in increasing air-sea gas flux. Nature 361(6413):620-623

Ford PW, Boon PI, Lee K (2002) Methane and oxygen dynamics in a shallow floodplain lake: the significance of periodic stratification. Hydrobiologia 485:97-110

Haeckel M, Boudreau BP, Wallmann K (2007) Bubble-induced porewater mixing: a 3-D model for deep porewater irrigation. Geochim Cosmochim Acta 71:5135-5154

Harley JF, Carvalho L, Dudley B, Heal KV, Rees RM, Skiba U (2015) Spatial and seasonal fluxes of the greenhouse gases $\mathrm{N}_{2} \mathrm{O}, \mathrm{CO}_{2}$ and $\mathrm{CH}_{4}$ in a UK macrotidal estuary. Estuar Coast Shelf Sci 153:62-73

Hershey AE, Northington RM, Whalen SC (2014) Substrate limitation of sediment methane flux, methane oxidation and use of stable isotopes for assessing methanogenesis pathways in a small arctic lake. Biogeochemistry 117(2-3):325-336

Hinrichs KU, Hayes JM, Bach W, Spivack AJ, Hmelo LR, Holm NG, Johnson CG, Sylva SP (2006) Biological formation of ethane and propane in the deep marine subsurface. PNAS 103(40): 14684-14689

Hornibrook ERC, Longstaffe FJ, Fyfe WS (2000) Evolution of stable carbon isotope compositions for methane and carbon dioxide in freshwater wetlands and other anaerobic environments. Geochim Cosmochim Acta 64(6):1013-1027

Jańczak J (1997) Atlas jezior Polski. T. 2: Jeziora zlewni rzek Przymorza i dorzecza dolnej Wisły. Bogucki Wydawnictwo Naukowe, Poznań

Jędrysek MO (1999) Spatial and temporal patterns in diurnal variations of carbon isotope ratios of early-diagenetic methane from freshwater sediments. Chem Geol 159:241-262

Juutinen S, Rantakari M, Kortelainen P, Huttunen JT, Larmola T, Alm J, Silvola J, Martikainen PJ (2008) Methane 
dynamics in different boreal lake types. Biogeosci Discuss 5:3457-3496

Kankaala P, Ojala A, Käki T (2004) Temporal and spatial variation in methane emissions from a flooded transgression shore of a boreal lake. Biogeochemistry 68:297-311

Karim A, Dubois K, Veizer J (2011) Carbon and oxygen dynamics in the Laurentian Great Lakes: implications for the $\mathrm{CO}_{2}$ flux from terrestrial aquatic systems to the atmosphere. Chem Geol 281:133-141

Katsman R, Ostrovsky I, Makovsky Y (2013) Methane bubble growth in fine-grained muddy aquatic sediment: insight from modeling. Earth Planet Sci Lett 377-378:336-346

Kinnaman FS, Valentine DL, Tyler SC (2007) Carbon and hydrogen isotope fractionation associated with the aerobic oxidation of methane, ethane, propane and butane. Geochim Cosmochim Acta 71:271-283

Kirschke S, Bousquet P, Ciais P, Saunois M, Canadell JG, Dlugokencky EJ, Bergamaschi P, Bergmann D, Blake DR, Bruhwiler L, Cameron-Smith P et al (2013) Three decades of global methane sources and sinks. Nat Geosci $6(10): 813-823$

Kjerfve B, Michener WK, Gardner LR (1994) Impacts of climate change in estuary and delta environments. In: Pernetta $J$ et al (eds) Impacts of climate change on ecosystems and species: marine and coastal ecosystems. A marine conservation and development report, IUCN, Gland, pp 31-44

Kotarba MJ, Nagao K (2015) Molecular and isotopic compositions and origin of natural gases from Cambrian and Carboniferous-Lower Permian reservoirs of the onshore Polish Baltic region. Int J Earth Sci (Geol Rundsch) 104:241-261

Laanbroek HJ (2010) Methane emission from natural wetlands: interplay between emergent macrophytes and soil microbial processes. A mini-review. Ann Bot 105:141-153

Leifer I, Patro RK (2002) The bubble mechanism for methane transport from the shallow sea bed to the surface: a review and sensitivity study. Cont Shelf Res 22:2409-2428

Leventhal JS, Guntenspergen GR (2004) Seasonal methane emissions by diffusion and ebullition from oligohaline marsh environments in coastal Louisiana. In: Hill RJ et al (eds) Geochemical investigations in earth and space science: a tribute to Isaac Kaplan, vol 9. The Geochemical Society, Washington, DC, pp 389-408

Liang JH, McWilliams JC, Sullivan PP, Baschek B (2011) Modelling bubbles and dissolved gases in the ocean. J Geophys Res 116:C03015

Liikanen A, Huttunen JT, Murtoniemi T, Tanskanen H, Väisänen T, Silvola J, Alm J, Martikainen PJ (2003) Spatial and seasonal variation in greenhouse gas and nutrient dynamics and their interactions in the sediments of a boreal eutrophic lake. Biogeochemistry 65:83-103

Liu R, Hofmann A, Gülaçar FO, Favarger PY, Dominik J (1996) Methane concentration profiles in a lake with permanently anoxic hypolimnion (Lake Lugano, Switzerland-Italy). Chem Geol 133:201-209

Lorenc H (1996) Struktura i zasoby energetyczne wiatru w Polsce. Materiały Badawcze, seria Meteorologia, 25. IMGW, Warszawa

Makhov GA, Bazhin NM (1999) Methane emission from lakes. Chemosphere 38(6):1453-1459
McGinnis DF, Greinert J, Artemov Y, Baeubien SE, Wüest A (2006) Fate of rising methane bubbles in stratified waters: how much methane reaches the atmosphere? J Geophys Res 111:C09007

McGinnis DF, Schmidt M, DelSontro T, Themann S, Rovelli L, Reitz A, Linke P (2011) Discovery of natural $\mathrm{CO}_{2}$ seep in the German North Sea: implications for shallow dissolved gas and seep detection. J Geophys Res 116:C03013

Miotk-Szpiganowicz G, Sz Uścinowicz, Zachowicz J (2008) Review and reinterpretation of pollen and diatom data from the deposits of the southern Baltic lagoons. Pol Geol Inst Spec Papers 23:45-70

Nakayama N, Watanabe S, Tsunogai S (2002) Nitrogen, oxygen and argon dissolved in the northern north Pacific in early summer. J Oceanogr 58:775-785

Olsson L, Ye S, Yu X, Wei M, Krauss KW, Brix H (2015) Factors influencing $\mathrm{CO}_{2}$ and $\mathrm{CH}_{4}$ emissions from coastal wetlands in the Liaohe Delta, Northeast China. Biogeosciences 12:4965-4977

Oremland RS (1981) Microbial formation of ethane in anoxic estuarine sediments. Appl Environ Microbiol 42(1): 122-129

Oremland RS, des Marais DJ (1983) Distribution, abundance and carbon isotopic composition of gaseous hydrocarbons in Big Soda Lake, Nevada: an alkaline, meromictic lake. Geochim Cosmochim Acta 47:2107-2114

Ostrovsky I, McGinnis DF, Lapidus L, Eckert W (2008) Quantifying gas ebullition with echosounder: the role of methane transport by bubbles in a medium-sized lake. Limnol Oceanogr 6:108-118

Sansone FJ, Holmes ME, Popp BN (1999) Methane stable isotopic ratios and concentrations as indicators of methane dynamics in estuaries. Global Biogeochem Cycle 13(2):463-474

Sapulveda-Jauregui A, Walter Anthony KM, Martinez-Cruz K, Greene S, Thalasso F (2015) Methane and carbon dioxide emissions from 40 lakes along a north-south latitudinal transect in Alaska. Biogeosciences 12:3197-3223

Scavia D, Field JC, Boesch DF, Buddemeier RW, Burkett V, Cayan DR, Fogarty M, Harwell MA, Howarth RW, Mason C, Reed DJ, Royer TC, Sallenger AH, Titus J (2002) Climate change impacts on U.S. coastal and marine ecosystems. Estuaries 25(2):149-164

Schouten S, Wakeham SG, Sinninghe Damsté JS (2001) Evidence for anaerobic methane oxidation by archaea in euxinic waters of the Black Sea. Org Geochem 32:1277-1281

Schubert C, Lucas FS, Durisch-Kaiser E, Stierli R, Diem T, Scheidegger O, Vazquez F, Müller B (2010) Oxidation and emission of methane in a monomictic lake (Rotsee, Switzerland). Aquat Sci 72:455-566

Sechman H, Kotarba MJ, Dzieniewicz M (2009) Surface geochemical survey at Starunia palaeontological site and vicinity (Carpathian region, Ukraine). Ann Soc Geol Pol 79(3):375-390

Segers R (1998) Methane production and methane consumption: a review of processes underlying wetland methane fluxes. Biogeochemistry 41:23-51

Skórczewski P, Mudryk ZJ (2005) Physiological properties of bacteria inhabiting coastal lake surface and subsurface water layers. Baltic Coast Zone 9:43-52 
StatSoft Inc. (2014) STATISTICA (data analysis software system), version 12. www.statsoft.com

Talbot M (2001) Nitrogen isotopes in palaeolimnology. In: Last WM, Smol JP (eds) Tracking environmental change using lake sediments, vol 2., Physical and geochemical methodsKluwer Academic Publishers, Dordrecht, pp 401-439

Utsumi M, Nojiri Y, Nakamura T, Nozawa T, Otsuki A, Seki H (1998) Oxidation of dissolved methane in a eutrophic, shallow lake: Lake Kasumiguara, Japan. Limnol Oceanogr 43(3):471-480

Walter KM, Chanton JP, Chaplin FS III, Schuur EAG, Zimov SA (2008) Methane production and bubble emissions from arctic lakes: isotopic implications for source pathways and ages. J Geophys Res 113:G00A08

Weiss RF (1970) The solubility of nitrogen, oxygen and argon in water and seawater. Deep Sea Res 17:721-735

Whiticar MJ (1999) Carbon and hydrogen isotope systematics of bacterial formation and oxidation of methane. Chem Geol $161: 291-314$
Whiticar M, Faber E (1986) Methane oxidation in sediment and water column environments-isotopic evidence. Org Geochem 10:759-768

Woszczyk M, Bechtel A, Kotarba MJ, Cieśliński R (2011) Composition and origin of organic matter in surface sediments of Lake Sarbsko: a highly eutrophic and shallow coastal lake (northern Poland). Org Geochem 42(9):1025-1038

Woszczyk M, Tylmann W, Jędrasik J, Szarafin T, Stach A, Skrzypczak J, Lutyńska M (2014) Recent sedimentation dynamics in a shallow coastal lake (Lake Sarbsko, northern Poland): driving factors, processes and effects. Mar Freshw Res 65(12):1102-1115

Yamamoto S, Alcauscas JB, Crozier TE (1976) Solubility of methane in distilled water and seawater. J Chem Eng Data 21(1):78-80

Yamamoto A, Yamanaka Y, Tajika E (2009) Modelling of methane bubbles released from large sea-flooor area: conditio required for methane emission to the atmosphere. Earth Planet Sci Lett 284:590-598 